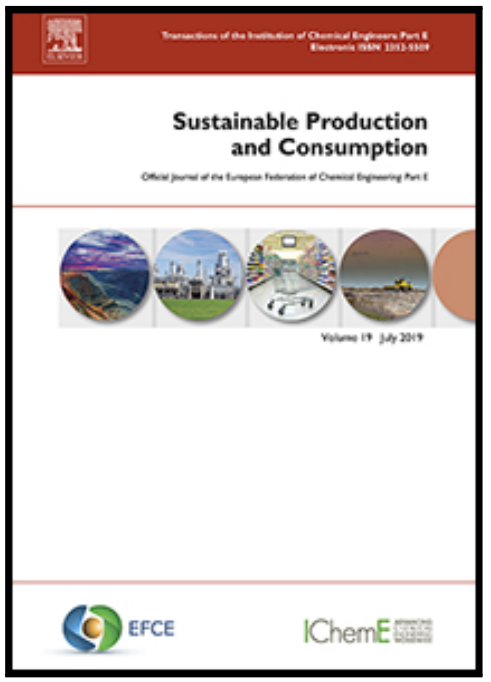

Strategies to improve energy and carbon efficiency of luxury hotels in Iran

Mohammad Salehi, Viachaslau Filimonau,

Mohammad Asadzadeh, Esmaeil Ghaderi

PII:

S2352-5509(20)30674-6

DOI:

https://doi.org/10.1016/j.spc.2020.09.007

Reference:

SPC 383

To appear in:

Sustainable Production and Consumption

Received date:

2 July 2020

Revised date:

12 September 2020

Accepted date:

13 September 2020

Please cite this article as: Mohammad Salehi, Viachaslau Filimonau, Mohammad Asadzadeh, Esmaeil Ghaderi, Strategies to improve energy and carbon efficiency of luxury hotels in Iran, Sustainable Production and Consumption (2020), doi: https://doi.org/10.1016/j.spc.2020.09.007

This is a PDF file of an article that has undergone enhancements after acceptance, such as the addition of a cover page and metadata, and formatting for readability, but it is not yet the definitive version of record. This version will undergo additional copyediting, typesetting and review before it is published in its final form, but we are providing this version to give early visibility of the article. Please note that, during the production process, errors may be discovered which could affect the content, and all legal disclaimers that apply to the journal pertain.

(C) 2020 Published by Elsevier B.V. on behalf of Institution of Chemical Engineers. 


\section{Strategies to improve energy and carbon efficiency of luxury hotels in Iran}

Mohammad Salehi ${ }^{1}{ }^{*}$, Viachaslau Filimonau $^{2}$, Mohammad Asadzadeh $^{3}$ and Esmaeil Ghaderi ${ }^{4}$

${ }^{1}$ Department of Tourism Management, Faculty of Management \& Accounting, Allameh Tabataba'i University, Tehran, Iran; email: mohamad.salehi1994@gmail.com

${ }^{2}$ Faculty of Management, Bournemouth University, Talbot Campus, Fern Barrow, Poole, Dorset, BH12 5BB, UK; email: vfilimonau@ bournemouth.ac.uk

${ }^{3}$ Department of Power Engineering, Faculty of Engineering, Azad University of Mashhad, Mashhad, Iran; email mohammadasadzadeh@outlook.com

${ }^{4}$ Department of Tourism Management, Faculty of Management \& Accounting, Allameh Tabataba'i University, Tehran, Iran; email: eghaderi2002@gmail.com

*Corresponding author 


\begin{abstract}
Luxury hotels generate substantial carbon footprint and scholarly research is urgently required to better understand how it could be effectively mitigated. This study adopts a method of life cycle energy analysis (LCEA) to assess the energy and carbon performance of six luxury, five star, hotels located in Iran. The results of the energy and carbon assessment of luxury hotels in Iran are compared against the energy and carbon values reported in past hotel research. This current study finds that luxury hotels in Iran are up to 3-4 times more energyand 7 times more carbon-intense than similar hotels examined in past research. Low cost of fossil fuels, international trade sanctions and the lack of governmental and corporate energy conservation targets discourage Iranian hoteliers from carbon footprint mitigation. To counteract poor energy and carbon efficiency of luxury hotels in Iran, it is important to relax economic sanctions, develop alternative energy sources, refine corporate energy conservation targets, regularly benchmark hotel energy performance and enable exchange of good practices among Iranian hoteliers.
\end{abstract}

\title{
Keywords
}

Tourist accommodation

Energy consumption

GHG emissions

Carbon mitigation

Middle East 


\section{Introduction}

Hotels consume excessive amounts of energy and, consequently, make a substantial contribution to climate change (Warren and Becken 2017). This is attributed to the continued growth of international tourism which generates circa $8 \%$ of global greenhouse gas (GHG) emissions (Lenzen et al. 2018). Currently, hotels hold a share of $21 \%$ in this carbon footprint (WTO and ITF 2019) but it is projected that, until 2035, it will increase to 25\% (De Grosbois and Fennell 2011).

The need to reduce the contribution of hotels to global carbon footprint and decrease their share in the GHG emissions of international tourism has been repeatedly called for (Teng et al. 2012). Scholarly research is gradually responding to this call by exploring the causes and effects of GHG emissions in hotels and examining approaches to mitigation (Michailidou et al. 2015). Despite growing academic interest, a number of shortfalls exist in an understanding of the carbon footprint of hotels (Koiwanit and Filimonau 2021).

First, there is no single, universal method to appraise the GHG emissions of hotel operations (Filimonau 2016). Not only does this hinder a cross-boundary and cross-sectoral comparison of the carbon performance of hotels, but also affects accuracy of carbon footprint estimates (Schianetz et al. 2007). This is a major shortcoming as a basic principle of business management suggests that 'if one cannot measure [something] accurately, one cannot manage it [effectively]' (Elimelech et al. 2018). It has therefore become ever important to identify the most cost-effective methods of carbon footprint assessment capable to accurately appraise the GHG emissions of hotels (De Grosbois and Fennell 2011). It has become equally important to test/validate the practical viability of these methods, using hotels from different consumption markets and accommodation types as empirical case studies (Filimonau et al. 2011b). Validation is however problematic as hotel's administrations do not always collaborate with scholars on such sensitive topics as environmental and/or energy 
management (Filimonau and Krivcova 2017). Substantial difficulties are reported by academics when attempting to access hotel premises for primary data collection and/or when requesting hotel managers to provide data on energy performance (Lai et al. 2012; Oluseyi et al. 2016). This is partially because energy use data are often considered confidential with resultant managerial reluctance to share these with scholars (Filimonau et al. 2011a).

Second, extant research on the carbon footprint of hotels has limited geographical coverage. Studies have assessed the GHG emissions of hotels in Europe (Puig et al. 2017), North America (Kelly and Williams 2007), Australia and Oceania (Becken et al. 2001), East Asia (Teng et al. 2012), South East Asia (Trung and Kumar 2005) and South Asia (Singh et al. 2014), but there remains a paucity of studies in South America, Africa and the Middle East (Warren and Becken 2016). This is a major omission as tourism is set to grow in these geographies (UNWTO 2019) which will accelerate the carbon footprint of hotels. To make tourism in these regions and in specific countries within these regions more climate-benign, future research should aim at accurately assessing the GHG emissions of hotels and then designing appropriate mitigation strategies.

This paper contributes to knowledge by assessing the carbon footprint of six luxury hotels in Iran through the lens of the method of life cycle energy analysis (LCEA). The choice of LCEA is deliberate as its scientific rigour in providing accurate carbon footprint appraisals of products and services has long been recognised, but it has been rarely applied to hotels (Filimonau et al. 2011a). This study provides further empirical evidence of the practical viability and cost-effectiveness of LCEA when applied within the hotel sector. The choice of Iran as a study geography is also deliberate. Although the country has experienced political isolation, its tourism industry is growing, mostly at the cost of domestic travel (Arefmanesh 2018), and so are the related GHG emissions of Iranian hotels. Carbon mitigation has now become a priority in Iran given the over-dependence of its economy on 
fossil fuels which has made Iran one of the key global carbon emitters (Ge and Friedrich 2020).

Studied hotels are luxury tourist accommodation properties in Iran whose administration agreed to collaborate on this project by providing researchers with access to their energy use data. In the context of this study, luxury hotels are understood as those tourist accommodation facilities providing significant levels of customer service and consumer amenities to ensure exceptional guest comfort which is line with the definition of luxury hotels used by Sourvinou and Filimonau (2018). Hereafter, wherever the term of luxury hotels is used, it refers to five-star hotels. Studied luxury hotel properties are so-called sector-typical hotels, or archetypes (Lai 2015), defined as the hotels that share operational characteristics of the majority of other hotels of the same comfort category, thus being largely representative of this specific category of hotels in Iran. The focus on the luxury segment of the hotel market is justified by the ability of luxury hotels to transform and lead the hotel sector in its quest towards the goal of environmental sustainability (Gardetti and Torres 2017). By establishing the patterns of energy consumption, revealing the magnitude of the related GHG emissions and adopting approaches to mitigation, luxury hotels in Iran can encourage other hoteliers to join the sector's pursuit towards more environmentally sustainable operations. According to Statistical Center of Iran (2017-2018), there are 36 luxury, five-star, hotels in Iran. This study has targeted $16.6 \%$ of them, i.e. 6 hotel properties, aiming to evaluate their energy use and carbon footprint performance. To enable a comparative analysis, the carbon footprint of luxury hotels is compared against the carbon footprint of a budget hotel which, again, is representative of the broader sub-sector of budget hotels in Iran.

The aim of this study is to assess the energy and carbon efficiency of luxury hotels in Iran and propose solutions to enhance their energy and carbon performance. In line with this 
aim, the research questions that this paper has set to answer are thus as follows: 1) 'What is the carbon footprint of luxury hotels in Iran?'; 2) 'How does it compare with the carbon footprint of hotels from other comfort categories in Iran?'; 3) 'How does the carbon footprint of luxury hotels in Iran compare against the carbon footprint of luxury hotels in other geographies?'; and 4) 'What (policy, management, market) interventions are necessary to mitigate the carbon footprint of Iranian hotels?'.

The rest of the paper is structured as follows. The study background including a review of the literature on the environmental externalities of hotels, a review of the environmental assessment methods, and a background of environmental management in the hotel sector of Iran are provided in Section 2. The details about the research method utilized in this investigation are provided in Section 3. The findings from the analysis and a discussion of these findings are presented in a merged form in section 4. Finally, section 5 elaborates upon the conclusions and policy implications of the findings, as well as provides recommendation for future research.

\section{Literature review}

\subsection{Environmental externalities of hotels}

Hotel operations are underpinned by a diversity of functions and services that produce disproportionate environmental externalities (Mensah and Blankson 2013). Hoteliers adopt these functions and services in pursuit of meeting guest expectations (Rico et al. 2019) as this is paramount to build customer loyalty which, in turn, raises business profitability (Kasim 2009). Although hotels rely on the provision of numerous environmental services to their guests, they tend to sacrifice the environment for the sake of revenue generation (Oluseyi et al. 2016). As a result, a typical hotel can annually consume up to 1000 tonnes of coal (Zhao 
et al. 2012) and release $160-200 \mathrm{~kg} \mathrm{CO}_{2}$ per $1 \mathrm{~m}^{2}$ of hotel's gross floor area (Legrand et al. 2017). Further, per guest night, a typical hotel can use 100-200 gallons of water (Zhang et al., 2010) and generate over $1 \mathrm{~kg}$ of solid waste (Bohdanowicz and Martinac 2007). At a global scale and in cumulative terms, the environmental externalities of hotels may have exceeded those of such traditionally resource-intense and pollution-heavy industries as chemical, manufacturing and agriculture (Legrand et al. 2017). This is alarming given the global hotel sector is rapidly expanding driven by a steady increase in international tourism (UNWTO 2019).

Hoteliers have started realising the disproportionate environmental footprint of hotel operations and their moral obligation to reduce its magnitude (Kasim 2009). As a result, a number of hotels have either adopted or, at least considered the adoption of, mitigation measures (Mensah 2006). However, the drivers behind this adoption remain pragmatic and clearly linked to business profitability (Erdogan and Baris 2007). Indeed, by embracing environmental conservation practices, hoteliers can save over $10 \%$ of their annual operational costs (Becken 2013). This can further aid hoteliers in building their business reputation as good corporate citizens, thus enhancing their position in highly competitive tourism marketplaces (Warnken et al. 2004). The purely non-pragmatic/non-utilitarian drivers of investing in environmental conservation in hotels are still rare (Abaeian et al. 2019).

Scholarly research has attempted to support hoteliers with their mission of (better) environmental sustainability by establishing the magnitude of the environmental impacts of hotels and revealing the main drivers, thus informing mitigation approaches. Table 1 reviews academic studies focusing on the topic of the environmental sustainability in hotels. It shows that recent research has become more specialised, complex and inter-disciplinary. Scholarly interest in the environmental sustainability of hotels has particularly grown since 2011, covering more geographies and addressing a wider range of environmental issues. This 
notwithstanding, studies focusing on Europe, East Asia \& the Pacific outnumber those conducted in South America, Africa and the Middle East.

Table 1. Studies on the environmental sustainability of hotels (since 2000).

\begin{tabular}{|c|c|c|c|c|c|c|c|}
\hline \multirow[b]{2}{*}{ Year } & \multirow[b]{2}{*}{ Source } & \multirow[b]{2}{*}{ Geographical focus } & \multirow[b]{2}{*}{$\begin{array}{l}\text { Environmental issue(s) } \\
\text { in focus }\end{array}$} & \multicolumn{3}{|c|}{ Scope of analysis } & \multirow[b]{2}{*}{$\begin{array}{l}\text { Assessment } \\
\text { method }\end{array}$} \\
\hline & & & & $\begin{array}{l}\text { Assessing } \\
\text { magnitude }\end{array}$ & $\begin{array}{l}\text { Establishing } \\
\text { drivers }\end{array}$ & $\begin{array}{l}\text { Designing } \\
\text { mitigation } \\
\text { approaches }\end{array}$ & \\
\hline 2019 & Rico et al. & Europe (Spain) & Energy, $\mathrm{CO}_{2}$ emissions & $X$ & - & $\mathrm{X}$ & Screening LCA \\
\hline 2019 & Gössling et al. & Europe (Spain) & Energy, water, chemicals & - & - & $\mathrm{X}$ & Field experiment \\
\hline 2019 & Pablo-Romero et al. & Europe (Spain) & Energy & $\mathrm{X}$ & $\mathrm{X}$ & $\mathrm{X}$ & $\begin{array}{l}\text { Using panel data } \\
\text { regression model }\end{array}$ \\
\hline 2019 & Pérez et al. & Europe (Spain) & $\begin{array}{l}\text { Energy, water, } \mathrm{CO}_{2} \\
\text { emissions }\end{array}$ & $\mathrm{X}$ & - & $\mathrm{X}$ & $\begin{array}{l}\text { Screening LCA } \\
\text { and regression } \\
\text { analysis }\end{array}$ \\
\hline 2019 & Dolnicar et al. & Europe (Slovenia) & $\mathrm{CO}_{2}$ emissions & 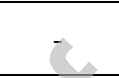 & - & $\mathrm{X}$ & $\begin{array}{l}\text { Quasi- } \\
\text { experiment }\end{array}$ \\
\hline 2018 & Sheng et al. & East Asia (China) & Energy & $\mathrm{X}$ & $\mathrm{X}$ & $X$ & $\begin{array}{l}\text { Computer } \\
\text { simulation }\end{array}$ \\
\hline 2017 & Kim and Oldham & $\begin{array}{l}\text { North America } \\
\text { (USA) }\end{array}$ & Energy & $\mathrm{X}$ & $\mathrm{X}$ & - & $\begin{array}{l}\text { Regression } \\
\text { analysis }\end{array}$ \\
\hline 2017 & Dolnicar et al. & Europe (Slovenia) & Energy, water, chemicals & - & - & $\mathrm{X}$ & Field experiment \\
\hline 2017 & Puig et al. & Europe (Spain) & $\begin{array}{l}\text { Energy, water, chemicals, } \\
\text { waste, GHG emissions }\end{array}$ & $\mathrm{X}$ & - & $\mathrm{X}$ & Screening LCA \\
\hline 2017 & Cvelbar et al. & Europe (Slovenia) & Energy, water, chemicals & - & - & $\mathrm{X}$ & Field experiment \\
\hline 2017 & Chan et al. & East Asia (China) & Indoor air quality & $\mathrm{X}$ & - & $X$ & $\begin{array}{l}\text { On-site } \\
\text { measurements }\end{array}$ \\
\hline 2017 & Michopoulos et al. & Europe (Cyprus) & Energy, $\mathrm{CO}_{2}$ emissions & $\mathrm{X}$ & - & $\mathrm{X}$ & $\begin{array}{l}\text { Carbon footprint } \\
\text { analysis }\end{array}$ \\
\hline 2017 & Abdulredha et al. & Middle East (Iraq) & Food waste & - & - & $\mathrm{X}$ & On-site survey \\
\hline 2017 & $\begin{array}{l}\text { Gabarda-Mallorquí } \\
\text { et al. }\end{array}$ & Europe (Spain) & Water & $\mathrm{X}$ & $\mathrm{X}$ & - & $\begin{array}{l}\text { Generalized } \\
\text { linear mixed } \\
\text { modelling }\end{array}$ \\
\hline 2017 & Mclennan et al. & Asia-Pacific & Water & $\mathrm{X}$ & $\mathrm{X}$ & - & $\begin{array}{l}\text { Regression } \\
\text { analysis }\end{array}$ \\
\hline 2016 & Kahn et al. & North America & Energy, $\mathrm{CO}_{2}$ emissions & $\mathrm{X}$ & $\mathrm{X}$ & - & $\begin{array}{l}\text { Carbon footprint } \\
\text { analysis }\end{array}$ \\
\hline 2016 & Pirani and Arafat & $\begin{array}{l}\text { Middle East (the } \\
\text { UAE) }\end{array}$ & Food waste & $\mathrm{X}$ & $\mathrm{X}$ & $\mathrm{X}$ & $\begin{array}{l}\text { Carbon footprint } \\
\text { and water } \\
\text { footprint } \\
\text { analyses }\end{array}$ \\
\hline 2016 & Oluseyi et al. & Africa (Nigeria) & Energy, GHG emissions & $\mathrm{X}$ & $\mathrm{X}$ & - & $\begin{array}{l}\text { Carbon footprint } \\
\text { and regression } \\
\text { analyses }\end{array}$ \\
\hline 2016 & Mardani et al. & Middle East (Iran) & Energy & - & - & $\mathrm{X}$ & $\begin{array}{l}\text { Fuzzy decision- } \\
\text { making analysis }\end{array}$ \\
\hline 2016 & Chang et al. & $\begin{array}{l}\text { North America } \\
\text { (USA) }\end{array}$ & Energy & - & - & $\mathrm{X}$ & $\begin{array}{l}\text { Scenario-based } \\
\text { experiment }\end{array}$ \\
\hline 2015 & Huang et al. & East Asia (Taiwan) & Energy, GHG emissions & $\mathrm{X}$ & $\mathrm{X}$ & - & $\begin{array}{l}\text { Screening LCA } \\
\text { and regression } \\
\text { analysis }\end{array}$ \\
\hline 2015 & Michailidou et al. & Europe (Greece) & $\begin{array}{l}\text { Energy, water, GHG } \\
\text { emissions }\end{array}$ & $\mathrm{X}$ & - & $\mathrm{X}$ & ECI and LCA \\
\hline 2015 & Hu et al. & East Asia (Taiwan) & $\begin{array}{l}\text { Energy, water, waste, } \\
\text { materials, GHG emissions }\end{array}$ & $\mathrm{X}$ & - & $X$ & $\begin{array}{l}\text { Screening LCA } \\
\text { (PAS 2050) }\end{array}$ \\
\hline 2015 & Lai & $\begin{array}{l}\text { East Asia (Hong } \\
\text { Kong) }\end{array}$ & $\begin{array}{l}\text { Energy, water, waste, } \\
\text { biomass, GHG emissions }\end{array}$ & $\mathrm{X}$ & $\mathrm{X}$ & $\mathrm{X}$ & $\begin{array}{l}\text { Screening LCA } \\
\text { and regression } \\
\text { analysis }\end{array}$ \\
\hline 2014 & Tsai et al. & East Asia (Taiwan) & Energy, $\mathrm{CO}_{2}$ emissions & $\mathrm{X}$ & $\mathrm{X}$ & $X$ & $\begin{array}{l}\text { Carbon footprint } \\
\text { analysis }\end{array}$ \\
\hline 2014 & Fazelpour et al. & Middle East (Iran) & Energy, GHG emissions & - & - & $\mathrm{X}$ & $\begin{array}{l}\text { Feasibility } \\
\text { assessment }\end{array}$ \\
\hline
\end{tabular}




\begin{tabular}{|c|c|c|c|c|c|c|c|}
\hline 2013 & Mak et al & East Asia (China) & Energy & $\mathrm{X}$ & $X$ & $\mathrm{X}$ & $\begin{array}{l}\text { Regression } \\
\text { analysis }\end{array}$ \\
\hline 2013 & Lu et al. & East Asia (China) & Energy & $\mathrm{X}$ & $X$ & - & $\begin{array}{l}\text { Regression } \\
\text { analysis }\end{array}$ \\
\hline 2013 & $\begin{array}{l}\text { Kallbekken and } \\
\text { Sælen }\end{array}$ & Europe (Norway) & Food waste & - & - & $\mathrm{X}$ & Field experiment \\
\hline 2012 & Castellani and Sala & Europe (Italy) & $\begin{array}{l}\text { Resource use, waste, } \\
\text { pollutant emissions }\end{array}$ & $\mathrm{X}$ & - & $X$ & LCA and EFA \\
\hline 2012 & Teng et al. & East Asia (Taiwan) & $\begin{array}{l}\text { Multiple, resource use and } \\
\text { non-resource use related, } \\
\text { impacts }\end{array}$ & - & - & $X$ & ECI \\
\hline 2012 & Ren et al. & Europe (Wales) & Energy, $\mathrm{CO}_{2}$ emissions & $\mathrm{X}$ & - & $\mathrm{X}$ & Screening LCA \\
\hline 2012 & Lai et al. & $\begin{array}{l}\text { East Asia (Hong } \\
\text { Kong) }\end{array}$ & $\begin{array}{l}\text { Energy, water, waste, } \\
\text { GHG emissions }\end{array}$ & $\mathrm{X}$ & - & - & Screening LCA \\
\hline 2012 & Aminian & Middle East (Iran) & Energy, water, waste & - & - & $X$ & $\begin{array}{l}\text { Qualitative } \\
\text { appraisal }\end{array}$ \\
\hline 2012 & Wang & East Asia (Taiwan) & Energy & $\mathrm{X}$ & $X$ & - & $\begin{array}{l}\text { Regression } \\
\text { analysis }\end{array}$ \\
\hline 2011 & Tortella and Tirado & Europe (Spain) & Water & $X$ & $X$ & - & $\begin{array}{l}\text { Regression } \\
\text { analysis }\end{array}$ \\
\hline 2011 & Chan et al. & East Asia (China) & Indoor air quality & & $X$ & - & $\begin{array}{l}\text { Field sampling } \\
\text { and laboratory } \\
\text { analysis }\end{array}$ \\
\hline 2011 & Chen and Hsieh & East Asia (Taiwan) & $\begin{array}{l}\text { Resource use (e.g., land, } \\
\text { energy, water, food), } \\
\text { waste }\end{array}$ & $\mathrm{X}$ & - & $X$ & EFA \\
\hline 2011 & Filimonau et al. & Europe (UK) & Energy, $\mathrm{CO}_{2}$ emissions & $\mathrm{X}$ & - & $\mathrm{X}$ & Screening LCA \\
\hline 2010 & Rossello-Batle et al. & Europe (Spain) & $\begin{array}{l}\text { Energy, waste, } \mathrm{CO}_{2} \\
\text { emissions }\end{array}$ & $\mathrm{X}$ & - & $X$ & Screening LCA \\
\hline 2010 & Xuchao et al. & $\begin{array}{l}\text { Southeast Asia } \\
\text { (Singapore) }\end{array}$ & Energy, $\mathrm{CO}_{2}$ emissions & $\mathrm{X}$ & $X$ & - & $\begin{array}{l}\text { Regression } \\
\text { analysis and } \\
\text { screening LCA }\end{array}$ \\
\hline 2009 & Priyadarsini et al. & $\begin{array}{l}\begin{array}{l}\text { Southeast Asia } \\
\text { (Singapore) }\end{array} \\
\end{array}$ & Energy & $\mathrm{X}$ & $X$ & - & $\begin{array}{l}\text { Regression } \\
\text { analysis }\end{array}$ \\
\hline 2008 & Goldstein et al. & $\begin{array}{l}\text { North America (the } \\
\text { United States) }\end{array}$ & Energy, water, chemicals & - & - & $X$ & Field experiment \\
\hline 2007 & $\begin{array}{l}\text { Bohdanowicz and } \\
\text { Martinac }\end{array}$ & Europe & Energy, water & $\mathrm{X}$ & $\mathrm{X}$ & - & $\begin{array}{l}\text { Regression } \\
\text { analysis }\end{array}$ \\
\hline 2006 & Chan et al. & East Asia (China) & Energy & $\mathrm{X}$ & - & $\mathrm{X}$ & Field experiment \\
\hline 2005 & Önüt and Soner & $\begin{array}{l}\text { Middle East } \\
\text { (Turkey) }\end{array}$ & Energy & $\mathrm{X}$ & - & $X$ & $\begin{array}{l}\text { Data } \\
\text { envelopment } \\
\text { analysis } \\
\end{array}$ \\
\hline 2004 & Warnken et al. & Oceania (Australia) & Energy & $\mathrm{X}$ & $X$ & - & $\begin{array}{l}\text { Regression } \\
\text { analysis } \\
\end{array}$ \\
\hline 2002 & $\begin{array}{l}\text { Shiming and } \\
\text { Burnett }\end{array}$ & $\begin{array}{l}\text { East Asia (Hong } \\
\text { Kong) }\end{array}$ & Energy & $\mathrm{X}$ & $\mathrm{X}$ & - & $\begin{array}{l}\text { Regression } \\
\text { analysis }\end{array}$ \\
\hline 2002 & Deng and Burnett & $\begin{array}{l}\text { East Asia (Hong } \\
\text { Kong) }\end{array}$ & Water & $\mathrm{X}$ & $X$ & - & $\begin{array}{l}\text { Regression } \\
\text { analysis }\end{array}$ \\
\hline 2001 & Becken et al & $\begin{array}{l}\text { Oceania (New } \\
\text { Zealand) }\end{array}$ & Energy & $\mathrm{X}$ & $X$ & - & $\begin{array}{l}\text { Regression } \\
\text { analysis }\end{array}$ \\
\hline 2000 & Deng and Burnett & $\begin{array}{l}\text { East Asia (Hong } \\
\text { Kong) }\end{array}$ & Energy & $X$ & $X$ & - & $\begin{array}{l}\text { Regression } \\
\text { analysis }\end{array}$ \\
\hline
\end{tabular}

Within the reviewed literature on the environmental sustainability of hotels, there have been repeated calls for the need to produce more accurate assessments of the GHG emissions (Rosselló-Batle et al. 2010; Filimonau et al. 2011a; Hu et al. 2015). Hotels represent one of the most energy-intense types of commercial buildings thereby making a noticeable 
contribution to climate change (Dascalaki and Balaras 2004). More research on the carbon footprint of hotels is required to establish the main drivers of energy use, thus designing (more) effective and (better) targeted mitigation strategies (Puig et al. 2017). Research on the carbon footprint of hotels is particularly needed for South America, Africa and the Middle East where tourism grows steadily (UNWTO 2019). These regions witness numerous environmental challenges where climate change represents an issue of major concern given its ability to accelerate such related environmental problems as water and food insecurity (Sieghart and Betre 2018). Climate change can further exacerbate numerous political and socio-economic issues that already exist within the regions in question, but also beyond (Stang 2016). One of the reasons behind the (yet) limited research agenda on the assessment of the GHG emissions from hotels in South America, Africa and the Middle East is in the under-developed methodological base of carbon footprint appraisals (Filimonau et al. 2011b).

\subsection{Methods to assess the environmental / carbon footprint of hotels}

\subsubsection{Ecological Footprint Analysis (EFA)}

The method of Ecological Footprint Analysis (EFA) represents an established tool to appraise the environmental externalities of products, services, economic sectors and entire countries (Wackernagel and Ress 1996). It is therefore unsurprising that past research has attempted to adopt it for application in tourism (see, for instance, World Wildlife Fund-UK 2002; Gössling et al. 2002; Patterson et al. 2007). The results of this research have however underlined such shortcomings of EFA as its high data quality requirements, tendency to over-estimate actual environmental impacts and limited value to inform the design of mitigation strategies (Hunter and Shaw 2007). Hence, only two studies on the environmental externalities of hotels are explicitly grounded on the method of EFA (Table 1) which is mainly because poor 
availability and insufficient quality of data on the environmental footprint of hotels makes it difficult to produce reliable and accurate assessments (Chen and Hsieh 2011). This was explicitly identified by Castellani and Sala (2012) who applied EFA to various types of hotels in Italy but concluded that the lack of site-specific data hampered the accuracy of appraisal and hindered the production of conclusions that could be of value for hotel administrations. By applying EFA to hotels in Taiwan, Chen and Hsieh (2011) generated more meaningful results due to better quality of primary data provided by hotel managers. The study established that energy use and food consumption were responsible for over $90 \%$ of the environmental footprint of the studied hotels. Grounding on this, various derivatives of EFA have been adopted to assess the water and carbon footprint of hotels (Table 1). These varied from narrow, specialised studies aiming to establish the impacts of hot water production technologies in hotels (Michopoulos et al. 2017), to the industry-broad research projects striving to evaluate energy efficiency of hotels across the entire country (Kahn et al. 2016).

\subsubsection{Environmental Composite Indicator/Index (ECI)}

The Organization for Economic Co-operation and Development (OECD) and the Joint Research Center (JCR) of the European Commission have proposed the method of Environmental Composite Indicator (ECI) to appraise the environmental externalities of products and services (JRC-European Commission 2008). The method is unique in that it can provide a balanced/weighted evaluation of the environmental impacts of a product or service across a number of impact categories (Dočekalová and Kocmanová 2015) and produce a clear set of managerial recommendations for impact mitigation (Mendola and Volo 2017). The application of ECI to hotels has however been limited to the study on the energy performance and carbon reduction potential of hotels in Taiwan (Teng et al. 2012) and to the appraisal of the environmental impacts of hotels in Greece (Michailidou et al. 2015), Table 1. 
Both studies highlighted such important shortcomings of ECI as poor data availability and quality (Blancas et al 2016) alongside the element of subjectivity involved in the evaluation, with subsequent weighting, of the environmental impacts of hotels (Salvati 2014).

\subsubsection{Life Cycle Assessment (LCA)}

The method of Life Cycle Assessment (LCA) has long been recognised as the most comprehensive approach to appraising the environmental externalities of products and services given it is underpinned by the 'cradle-to-grave' considerations (Klöpffer 2003). Similar to ECI, LCA can assess multiple environmental impacts including those attributed to the non-operational inputs of energy and material (Frischknecht et al. 2007). Unlike EFA which provides a limited insight into possible impact mitigation options for managers, LCA can inform the design of mitigation strategies by outlining areas (with a product's or service's lifecycle) with the largest environmental footprint (Wolf et al. 2012).

As for the potential of LCA to be applied for assessment of the environmental externalities of hotels, similar to the methods of EFA and ECI, its major shortcoming is in data availability (Schianetz et al. 2007). The truly comprehensive, from cradle-to-grave, assessment requires primary data of exceptional quality, which is rarely the case for hotels (Castellani and Sala 2012). Another drawback is the cost of analysis as, for better efficiency, the lifecycle data need to be processed in specialist software which is expensive for hotels to procure and difficult to operate (De Camillis et al. 2010). To make the method of LCA more cost-effective, a number of streamlined, or screening, derivatives have emerged. For example, the method of Life Cycle Energy Analysis (LCEA) has been proposed to appraise the energy consumption and assess the related carbon footprint of hotels (Filimonau 2016). By focusing on a single environment impact, i.e. climate change, LCEA is able to (better) address the 
issue of data quality whilst concurrently reducing the cost of assessments given that no

laborious field work and analysis is required (Filimonau et al. 2011a). A number of studies

have applied such screening LCA methods in practice (Table 1) and Table 2 reviews the

instances of their application to hotels in detail.

Table 2. LCA-based studies of hotels.

\begin{tabular}{|c|c|c|c|c|c|c|c|c|c|}
\hline \multirow[b]{2}{*}{ Reference } & \multirow[b]{2}{*}{$\begin{array}{l}\text { Object and } \\
\text { location }\end{array}$} & \multirow[b]{2}{*}{$\begin{array}{l}\text { Functional unit/ } \\
\text { Benchmarking } \\
\text { indicator }\end{array}$} & \multicolumn{5}{|c|}{ System boundary and scope } & \multirow[b]{2}{*}{$\begin{array}{c}\text { Main source of } \\
\text { environmental } \\
\text { impacts in hotels / } \\
\text { Identified hotspots }\end{array}$} & \multirow[b]{2}{*}{$\begin{array}{l}\text { Primary data } \\
\text { sources }\end{array}$} \\
\hline & & & 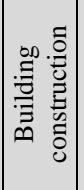 & 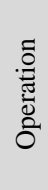 & 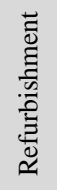 & 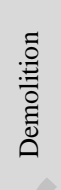 & 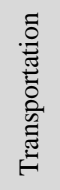 & & \\
\hline Rico et al. (2019) & 53 hotels in Spain & $\begin{array}{l}\text { Per guest night stay; } \\
\text { per room day }\end{array}$ & - & $\mathrm{X}$ & - & - & & $\begin{array}{l}\text { Electricity } \\
\text { consumption }\end{array}$ & $\begin{array}{l}\text { Secondary data from } \\
\text { the literature }\end{array}$ \\
\hline $\begin{array}{l}\text { Neugebauer } \text { et al. } \\
(2020)\end{array}$ & Hotel in Germany & Per guest night stay & - & $\mathrm{X}$ & & & - & Not clearly stated & $\begin{array}{l}\text { Secondary data from } \\
\text { the literature }\end{array}$ \\
\hline Pérez et al. (2019) & 12 hotels in Spain & Per guest night stay & - & $x$ & & - & - & $\begin{array}{l}\text { Electricity } \\
\text { consumption }\end{array}$ & $\begin{array}{l}\text { On-site data } \\
\text { collection }\end{array}$ \\
\hline Puig et al. (2017) & 14 hotels in Spain & Per guest night stay & & $\mathrm{X}^{\mathrm{a}}$ & - & - & - & $\begin{array}{l}\text { Electricity and fuel } \\
\text { consumption in the } \\
\text { use phase }\end{array}$ & $\begin{array}{l}\text { On-site data } \\
\text { collection }\end{array}$ \\
\hline Hu et al. (2015) & Hotel in Taiwan & $\begin{array}{l}\text { Per gross floor area } \\
\text { and guest night stay }\end{array}$ & & $X^{b}$ & - & - & $X^{c}$ & $\begin{array}{l}\text { Electricity } \\
\text { consumption in the } \\
\text { use phase }\end{array}$ & $\begin{array}{l}\text { On-site data } \\
\text { collection }\end{array}$ \\
\hline $\begin{array}{l}\text { Michailidou et al. } \\
\text { (2015) }\end{array}$ & 16 hotels in Greece & $\begin{array}{l}\text { Surface area; Guest } \\
\text { nights; Number of } \\
\text { guest rooms }\end{array}$ & - & $\mathrm{X}$ & - & - & $X^{d}$ & Not clearly stated & $\begin{array}{l}\text { On-site data } \\
\text { collection }\end{array}$ \\
\hline Lai (2015) & $\begin{array}{l}3 \text { hotels in Hong } \\
\text { Kong }\end{array}$ & $\begin{array}{l}\text { Total floor area and } \\
\text { number of guest } \\
\text { rooms }\end{array}$ & - & $\mathrm{X}$ & - & - & $X^{\mathrm{e}}$ & $\begin{array}{l}\text { Electricity } \\
\text { consumption in the } \\
\text { use phase }\end{array}$ & $\begin{array}{l}\text { On-site data } \\
\text { collection }\end{array}$ \\
\hline $\begin{array}{l}\text { Huang et al. } \\
\text { (2015) }\end{array}$ & 58 hotels in Taiwan & Per gross floor area & - & $\mathrm{X}$ & - & - & - & $\begin{array}{l}\text { Electricity } \\
\text { consumption }\end{array}$ & $\begin{array}{l}\text { Phone interviews } \\
\text { and on-site data } \\
\text { collection }\end{array}$ \\
\hline $\begin{array}{l}\text { El Hanandeh } \\
\text { (2013) }\end{array}$ & $\begin{array}{l}\text { Hotels in Saudi } \\
\text { Arabia }\end{array}$ & Per guest night stay & $\mathrm{X}$ & $\mathrm{X}$ & - & - & - & Not clearly stated & $\begin{array}{l}\text { Secondary data from } \\
\text { the literature }\end{array}$ \\
\hline $\begin{array}{l}\text { Filimonau et al. } \\
\text { (2013) }\end{array}$ & Hotel in Portugal & Per guest night stay & $X^{f}$ & $\mathrm{X}$ & - & - & - & Direct emissions & $\begin{array}{l}\text { On-site data } \\
\text { collection }\end{array}$ \\
\hline $\begin{array}{l}\text { Castellani and } \\
\text { Sala (2012) }\end{array}$ & Hotel in Italy & Per guest night stay & $\mathrm{X}$ & $X^{g}$ & $\mathrm{X}$ & $\mathrm{X}$ & - & $\begin{array}{l}\text { Electricity use in the } \\
\text { operational phase }\end{array}$ & $\begin{array}{l}\text { On-site data } \\
\text { collection }\end{array}$ \\
\hline Lai et al. (2012) & Hotel in Hong Kong & Per room-day & - & $\mathrm{X}$ & - & - & - & Electricity usage & $\begin{array}{l}\text { On-site data } \\
\text { collection }\end{array}$ \\
\hline Ren et al. (2012) & Hotel in the UK & Not defined & $\mathrm{X}$ & - & - & - & $\mathrm{X}^{\mathrm{h}}$ & Materials delivery & On-site data \\
\hline $\begin{array}{l}\text { Filimonau et al. } \\
\text { (2011b) }\end{array}$ & Hotel in the UK & Per guest night stay & - & $\mathrm{X}$ & - & - & - & $\begin{array}{l}\text { Electricity } \\
\text { consumption }\end{array}$ & $\begin{array}{l}\text { Secondary data from } \\
\text { the literature }\end{array}$ \\
\hline $\begin{array}{l}\text { Filimonau et al. } \\
\text { (2011a) }\end{array}$ & 2 hotels in the UK & $\begin{array}{l}\text { Per gross floor area } \\
\text { and number of guest } \\
\text { nights }\end{array}$ & $X^{f}$ & $X^{i}$ & - & - & $\mathrm{X}^{\mathrm{j}}$ & $\begin{array}{l}\text { Electricity use in the } \\
\text { operational phase }\end{array}$ & $\begin{array}{l}\text { On-site data } \\
\text { collection }\end{array}$ \\
\hline $\begin{array}{l}\text { Xuchao et al. } \\
\text { (2010) }\end{array}$ & $\begin{array}{l}29 \text { hotels in } \\
\text { Singapore }\end{array}$ & $\begin{array}{l}\text { Per gross floor area } \\
\text { and number of room } \\
\text { nights }\end{array}$ & - & $\mathrm{X}$ & - & - & - & $\begin{array}{l}\text { Electricity } \\
\text { consumption }\end{array}$ & $\begin{array}{l}\text { Data from a national } \\
\text { survey }\end{array}$ \\
\hline $\begin{array}{l}\text { Rosselló-Batle et } \\
\text { al. (2010) }\end{array}$ & 2 hotels in Spain & Per $1 \mathrm{~m}^{2}$ of built area & $\mathrm{X}^{\mathrm{k}}$ & $X^{1}$ & $\mathrm{X}$ & $\mathrm{X}^{\mathrm{m}}$ & $\mathrm{X}^{\mathrm{n}}$ & Operational phase & $\begin{array}{l}\text { On-site data } \\
\text { collection }\end{array}$ \\
\hline
\end{tabular}

\section{Remarks:}

a. in addition to energy and water consumption, included use of chemicals, waste generation and treatment 
b. included resource consumption, outsourced laundry services and sewage disposal discharge

c. included outsourced laundry services, transport of goods to the hotel and removal of waste

d. included travel by hotel guests

e. included travel by hotel staff and guests

f. based on estimates extracted from the literature

g. included resource consumption, waste generation and food services

h. included all construction-related transportation activities

i. included operational energy use and energy embodied in catering and laundry services

j. included transportation service for food delivery

$\mathrm{k}$. included construction materials and construction waste

1. included operational energy use and waste generation

$\mathrm{m}$. an approximation was done

n. restricted to transportation in the demolition phase

Table 2 demonstrates that most LCA-based studies are concerned with carbon footprint, justifying this by its disproportionate contribution to the overall environmental externalities of hotels (Xuchao et al 2010). The issue of carbon footprint is further seen as being of prime concern for hotel administration given that energy conservation is closely linked to business profitability and reputation (Rosselló-Batle et al 2010). Lastly, undertaking a multi-impact appraisal is often considered unviable due to the poor quality of non-energy use data and the high cost of their procurement (Castellani and Sala 2012); it is further because many hotel managers do not clearly understand such environmental externalities as, for example, ecotoxicity or eutrophication and how these can be mitigated in situ (Filimonau et al. 2011a).

Due to problems with data availability and accessibility, most studies choose to focus on specific stages of the hotel's business lifecycle. For instance, Ren et al (2012) appraised the carbon implications of constructing a hotel building in the UK and Huang et al. (2015) assessed the GHG emissions from hotel operations in Taiwan. Past research has concluded that the operational stage of a hotel business's lifecycle generates the largest proportion of its total carbon footprint and should therefore be focussed on for better cost-effectiveness of appraisals (Filimonau 2016). For example, Rosselló-Batle et al. (2010) revealed that the operational phase of hotel buildings' lifecycle in a sample of hotels in Spain was 6-11 times more carbon intense than the construction phase. Likewise, Hu et al. (2015) found that the 
operational phase of a hotel business in Taiwan was responsible for $88 \%$ of its total carbon footprint.Likewise, Puig et al. (2017) identified that operational energy use in Spanish hotels produced $75 \%$ of their total GHG emissions while the contribution of water consumption, use of chemicals and solid waste generation was marginal. This contribution was calculated even higher at $97 \%$ in the recent study conducted by Rico et al. (2019). Following these findings, Filimonau et al. (2011a) proposed that future carbon footprint appraisals of hotels should be concerned with collecting primary data on operational energy use only while the nonoperational GHG emissions should be estimated as being equal to $15 \%$ of the operational carbon footprint. This is to make studies more cost-, time- and labour-effective, but also to tackle the issue of primary data availability and quality.

In summary, screening LCA represents an accurate, yet cost-effective, method of appraising GHG emissions of hotels, establishing the 'hot-spots' in carbon footprint generation and highlighting mitigation opportunities for hotel administration. This notwithstanding, studies underpinned by this method remain small in number and cover only a handful of geographies. No research has attempted to adopt LCA to appraise the GHG emissions of hotels in Iran, a large Middle East's economy with an established hotel sector. This study will partially fill this knowledge gap.

\subsection{The hotel sector of Iran and the environmental management within}

Despite the abundance of natural and cultural heritage which traditionally attracts tourists, the tourism market in Iran is immature (Morakabati 2011). Two fundamental, internal and external, factors hinder tourism development. The internal factor is attributed to the organisational and institutional challenges in Iran. Up until August 2019, there was no dedicated Iranian ministry to deal with tourism and any tourism planning and development 
tasks were fulfilled by a public body called the 'Iran Cultural Heritage, Handicrafts and Tourism Organization'. The work of this organisation was repeatedly criticized for the lack of tourism-specific expertise, poor leadership and limited agility to market changes (Khodadadi 2016a). The external factor in the under-development of the tourism market in Iran relates to the political and economic challenges experienced by the country on the international arena. This includes punitive sanctions, currency fluctuations, economic overdependence on oil revenues and the prevalence of Iran-phobia among prospective international tourists (Khodadadi 2016a).

Due to these factors, in recent years, the inbound tourism market in Iran has stagnated. From 2013 to 2017, the number of international tourists had fluctuated at around 5 million. Followed by an increase of $4.2 \%$ over the period of $2013 / 14$, tourist numbers peaked at just over 5.2 million in 2015 (UNWTO 2017), then fell back to just under 4.9 million in 2016 (UNWTO 2018). After years of stagnation, in 2018, inbound tourism reached its second highest point at circa 7.3 million (UNWTO 2019). Most international tourists arrive to Iran from the neighbouring countries of Iraq (approximately 2.6 million), Azerbaijan (circa 1.8 million), Afghanistan (circa 1 million), Turkey (just under 0.9 million) and Pakistan (nearly 0.3 million) (ICHHTO 2019-2020). Despite a relatively small size of inbound tourism in Iran, the contribution of this industry to the country's GDP is estimated at 7.5\% (Central Bank of Iran 2018) which signifies its power as an economic activity of national importance, especially in light of Iran's over-dependence on oil extraction. Domestic tourism contributes with nearly 80\% to tourism's GDP of Iran (WTTC 2017) with 182 million trips undertaken by Iranians every year (ICHHTO 2018-2019).

The hotel sector in Iran reflects the effect of the current stagnation in national tourism. Due to a small number of international tourists, foreign hospitality brands are reluctant to invest in Iran (Ghaderi et al. 2019). Hence, local hospitality companies, driven by a steady 
growth in domestic tourism, have been leading the development of the national hotel market (Khodadadi 2016b). Today, there are 1387 registered hotels in Iran (accommodating 305510 beds) with the low-cost/low-comfort market categories, i.e. one- and two-star hotels, cumulatively occupying 52\% of the Iranian hotel market (370 and 348 properties, respectively) followed by budget, three-star, hotels (21\% or 294 properties), unclassified/nonstar (17\% or 234 properties) and upmarket, four-star, hotels (7\% or 105 properties) (ICHHTO 2018-2019). $3 \%$ of the market share (or 36 properties) belongs to luxury, five-star, hotels (SCI 2017-2018).

The dominance of low-cost/low-comfort and budget hotel categories is due to the low purchasing power of domestic tourists in Iran. These properties are usually very basic with limited guest amenities (SCI 2020). The upmarket and, especially, luxury hotels cater for international tourists as well domestic business travellers and domestic affluent tourists. These properties normally have a broad range of guest amenities on offer. Further, compared to other hotel categories, luxury hotels have better (financial and labour) resources which, in theory, should enable them to invest in solving such operational issues as the environmental sustainability. In line with its Sixth Five-Year Economic, Cultural, and Social Development Plan (2016-2021), the Iranian government is keen to increase the total number of hotels, especially four- and five-star properties, in an attempt to build loyalty of international and business tourists (ICHHTO 2018-2019).

Scholarly research on the environmental management in Iranian hotels lags behind and the Scopus/Google Scholar search undertaken on this topic revealed only three studies published in peer-reviewed, English-speaking, academic literature (Aminian 2012; Fazaelpour et al. 2014; Mardani et al. 2016), (Table 1). The focus of these studies was however on either energy efficiency management or environmental decision-making in hotels, rather than on energy and carbon audit. It is argued that effective environmental 
decision-making in hotels should be underpinned by a sound understanding of the exact magnitude of environmental issues in focus, which is the exact focus of this study.

Despite the lack of research, it is perceived that hotels in Iran tend to underestimate the value played by various environmental services in their day-to-day operations and, as a result, overlook environmental standards in hotel building construction and design, consume excessive energy, water and other resources and mismanage waste. It is further perceived that hotels in Iran take a passive role in training their staff and educating guests in energy conservation. Importantly, the hotel sector in Iran has not been captured by the national inventories of GHG emissions (see, for example, National Climate Change Office 2010). In fact, such inventories treat hotels as part of the commercial building stock which hampers distinguishing their carbon performance from that of other commercial buildings in Iran. This further impedes a comparative analysis of the GHG emissions of Iranian hotels against hotels of similar comfort categories located in other geographies. The above underlines an important knowledge gap and justifies the need for the current study.

\section{Methods}

\subsection{Case study hotels}

Study participants were recruited from among luxury hotels in Iran. To this end, faxes were sent to owners/managers of all luxury hotel properties introducing the project and explaining its goals. This was followed up with personal phone calls aiming at providing further project's details and securing permission of hotel managers to partake in an energy audit.

Six hotels, making up 17\% of all luxury hotels in Iran (SCI, 2017-2018), provided consent to participate in this study. Not being limited to a narrow geographical area, these surveyed hotels came from different regions of Iran, despite the added difficulties to field 
visits. It does matter since weather conditions, flow of capital and knowledge, characteristics of tourism markets and, following these, hotels' operational and physical features, differ from region to region in Iran or, indeed, in other tourist destinations. Three of the surveyed hotels belonged to a large owner and operator of luxury, five-star, hotels in Iran. These three properties were located in Mashhad, Kerman and Khuzestan provinces of Iran. The remaining three properties each owned by a separate hotel chain are located in Tehran (Figure 1). While Tehran is an ideal destination for business travellers, Mashhad is one of the main hubs of religious tourism in Iran. In addition to their historical attractiveness, Kerman, due to proximity to the Lut dessert, and Ahvaz, due to proximity to important rivers and the Persian Gulf coast, are popular with leisure holidaymakers. Moreover, because of the differences in their surrounding natural environment and population density, these cities are representative of different climates in Iran (Roshan et al. 2017).

The physical and operational parameters of the surveyed luxury hotels of relevance to this study differ from each other (Table 3). For the purpose of data privacy, they are labelled thereafter as Hotel A-F. As can be seen in the table, there is a significant discrepancy between GFA and number of guest nights of Hotel F and those of Hotel C, for instance. Another noticeable difference is observed between occupancy rates of Hotels $\mathrm{F}$ and $\mathrm{E}$, where the occupancy rate of Hotel $\mathrm{F}$ is 1.6 times larger than the one recorded for hotel E. However, the case study hotels are representative of the luxury hotel category in Iran. That is, there are minor differences between their major physical and operational characteristics and those of Iranian luxury hotels not investigated in this study. This was revealed through personal communication with the representatives of these companies' administrations and the chief of the Iran's Hotel Associations, where it was realized that their room occupancy (40-60\%) and annual number of guest nights (above 20000) were similar to other luxury hotel properties in Iran. This was further re-confirmed by comparing the features of the case studied properties 
with those reported on corporate websites of other luxury hotels in Iran. All this evidence suggests that the case study hotels can be labelled as sector-typical, or representative, archetypes for the luxury hotel sector of Iran. This is particularly valuable as this means that the results of the carbon footprint appraisal undertaken in this study can be subsequently extrapolated to provide an insight into the GHG emissions of other luxury hotel properties in Iran.

For a comparative analysis, a case study hotel representing a low-cost/low-comfort segment of the hotel market in Iran was added to the sample (labelled thereafter as Hotel X). This was an independent city hotel and its choice was driven by its operational characteristics that were largely typical, representative, of other hotels in Iran within the low-cost/lowcomfort category in terms of their room occupancy rates (40-50\%) and the annual number of guest night stays (5000-10000), Table 3.

Table 3. General characteristics of the case study hotels. Data are valid for the operations year of 2016-2017.

\begin{tabular}{|c|c|c|c|c|c|c|c|}
\hline Characteristic & Hotel A & Hotel B & Hotel C & Hotel D & Hotel E & Hotel F & Hotel X \\
\hline Location & $\begin{array}{l}\text { Mashhad, Razavi } \\
\text { Khorasan } \\
\text { province }\end{array}$ & $\begin{array}{l}\text { Kerman, } \\
\text { Kerman } \\
\text { province }\end{array}$ & $\begin{array}{c}\text { Ahvaz, } \\
\text { Khuzestan } \\
\text { province }\end{array}$ & $\begin{array}{c}\text { Tehran, } \\
\text { Tehran } \\
\text { province }\end{array}$ & $\begin{array}{c}\text { Tehran, } \\
\text { Tehran } \\
\text { province }\end{array}$ & $\begin{array}{c}\text { Tehran, } \\
\text { Tehran } \\
\text { province }\end{array}$ & $\begin{array}{c}\text { Abadeh, Fars } \\
\text { province }\end{array}$ \\
\hline Geography type & \multicolumn{7}{|c|}{ City hotel } \\
\hline $\begin{array}{c}\text { Operational } \\
\text { season }\end{array}$ & \multicolumn{7}{|c|}{ Full, 365 days } \\
\hline Category & $5 *$ & $5 *$ & $5 *$ & $5^{*}$ & $5 *$ & $5 *$ & $2 *$ \\
\hline Number of floors & $6+5+6$ floors & 11 floors & 7 floors & 14 floors & 20 floors & 29 floors & 4 floors \\
\hline $\begin{array}{l}\text { Type of a hotel } \\
\text { building } \\
\text { construction }\end{array}$ & $\begin{array}{c}\text { Three } \\
\text { interconnected } \\
\text { buildings }\end{array}$ & \multicolumn{6}{|c|}{ Building of separate standing } \\
\hline $\operatorname{GFA}\left(\mathrm{m}^{2}\right)$ & 39135.14 & 32000 & 10247.5 & 23400 & 23000 & 51800 & 2440 \\
\hline $\begin{array}{l}\text { Year of building } \\
\text { construction }\end{array}$ & 1995 & 1994 & 1968 & 1969 & 1969 & 1971 & 1971 \\
\hline $\begin{array}{l}\text { Number of } \\
\text { guestrooms }\end{array}$ & 229 & 197 & 135 & 374 & 177 & 489 & 28 \\
\hline $\begin{array}{l}\text { Annual occupancy } \\
\text { (in \% of rooms } \\
\text { occupied) }\end{array}$ & $50 \%$ & $42 \%$ & $60 \%$ & $53 \%$ & $38 \%$ & $63 \%$ & $40 \%$ \\
\hline $\begin{array}{l}\text { Occupancy (in \% } \\
\text { of beds occupied) }\end{array}$ & $15 \%$ & $17 \%$ & $22 \%$ & - & $27 \%$ & $37 \%$ & $25 \%$ \\
\hline $\begin{array}{l}\text { Number of guest } \\
\text { nights per annum }\end{array}$ & 25322 & 24842 & 23673 & - & 36886 & 90664 & 8172 \\
\hline In-house laundry & Yes & Yes & Yes & Yes & Yes & Yes & Yes \\
\hline $\begin{array}{c}\text { In-house } \\
\text { restaurant }\end{array}$ & Yes & Yes & Yes & Yes & Yes & Yes & Yes \\
\hline
\end{tabular}




\begin{tabular}{|c|c|c|}
\hline $\begin{array}{c}\text { Facilities and } \\
\text { services offered }\end{array}$ & Guest accommodation / Catering / Laundry / Conference facilities / Sports facilities / Guest shop/ & $\begin{array}{c}\text { Guest } \\
\text { accommodation } \\
\text { / Catering / } \\
\text { Laundry / } \\
\text { Parking }\end{array}$ \\
\hline $\begin{array}{c}\text { Energy- } \\
\text { consuming } \\
\text { services }\end{array}$ & Parking \\
\hline $\begin{array}{c}\text { Main energy } \\
\text { sources }\end{array}$ & Guest rooms, HVAC, hot water, cooking, laundry, elevators \\
\hline
\end{tabular}

\subsection{Primary data collection}

Primary data were collected via an annual on-site survey of energy use conducted upon securing consent of case study hotels' administration. The survey ran during the course of the Iranian calendar year, i.e. beginning from $21^{\text {st }}$ March 2016 to $20^{\text {th }}$ March 2017, and aimed to accurately record all instances of energy use in the studied hotels' buildings. Survey data were subsequently compared with energy invoices provided by the studied hotels in order to confirm survey data reliability and validate the correctness of seasonal patterns of energy use.

Following this, interviews with senior managers of the studied hotels were held. This procedure follows the approach of carbon footprint assessment introduced by Koiwanit and Filimonau (2021). During these interviews, the data collected in the survey and subsequently validated via desk-based research, as per above, were presented to senior hotel managers. Managers were requested to confirm that the primary data obtained were consistent with their expectations of the energy performance of their hotels and in line with such data for past years. This was to ensure that the data collected contained no outliers caused, for example, by unusual seasonal or annual variations in room/guest occupancy This was further to guarantee that the data were representative of a 'normal' hotel building's pattern of energy use across past years of business operations. Interviews confirmed this was the case.

Figure 1. Geographical locations of the case studied hotels 


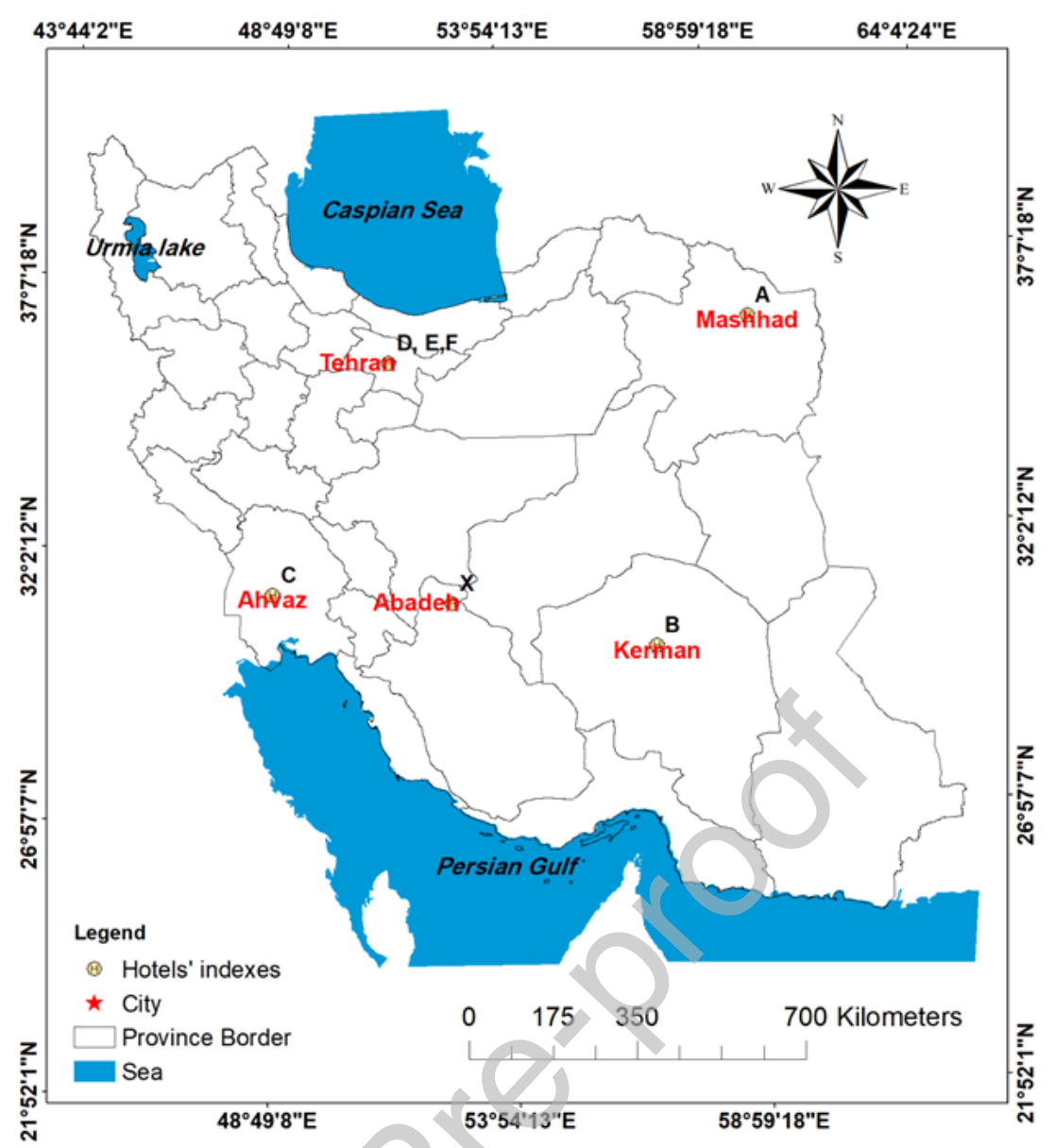

\subsection{Primary data analysis}

To convert energy data into the corresponding greenhouse gas emissions, appropriate emission factors must be adopted (Filimonau 2016). The standard emission factors annually released by the Iranian Ministry of Energy (2018-2019) were employed for this purpose. Hotels in Iran consume energy from two sources: electricity (predominantly for airconditioning and lightning) and natural gas (mostly for heating and cooking). Given the mixture of electricity production in the country, in 2016-2017, $1 \mathrm{kWh}$ of electricity in Iran generated an average of $0.64 \mathrm{CO}_{2} \mathrm{~kg}$. For natural gas, the default emission factor is 4.89 $\mathrm{kg} / \mathrm{m}^{3}$ which is an equivalent of $0.47 \mathrm{CO}_{2} \mathrm{~kg} / \mathrm{kWh}$. For the purpose of unifying the two units, the electricity equivalent of natural gas, i.e. $10.34 \mathrm{kWh} / \mathrm{m}^{3}$ (Iranian Ministry of Energy 20182019), was utilized. 
Energy use and the related carbon footprint were calculated per guest night stay and per unit of gross floor area $\left(\mathrm{m}^{2}\right.$ of GFA or energy use index in the case of energy consumption) of the studied hotels (Table 4). The latter is a well-established unit in research on energy use in commercial buildings, including hotels (see, for example, Dascalaki and Balaras 2004; Oluseyi et al. 2016; Puig et al. 2017) while the former indicator has been repeatedly used in studies on energy consumption and carbon footprint in the hotel sector (see, for instance Castellani and Sala 2012; De Camillis et al. 2010; Filimonau et al. 2011a; Rico et al. 2019). Both indicators were employed to enable analysis of this study's findings against the results reported in past research.

Table 4. Energy use characteristics of the surveyed hotels.

\begin{tabular}{|c|c|c|c|c|c|c|c|}
\hline Characteristic & Hotel A & Hotel B & Hotel C & Hotel D & Hotel E & Hotel F & Hotel X \\
\hline \multicolumn{8}{|c|}{ Energy use (kWh/guest night): } \\
\hline TOTAL & $867(100 \%)$ & $448(100 \%)$ & $189(100 \%)$ & - & $344(100 \%)$ & $229(100 \%)$ & $76(100 \%)$ \\
\hline Electricity & $116(13 \%)$ & $81(18 \%)$ & $106(56 \%)$ & - & $120(35 \%)$ & $64(28 \%)$ & $10(13 \%)$ \\
\hline Natural gas & $751(87 \%)$ & $367(82 \%)$ & $83(44 \%)$ & - & $224(65 \%)$ & $165(72 \%)$ & $66(87 \%)$ \\
\hline AVERAGED & & $-1-1$ & 41 & & & & 76 \\
\hline \multicolumn{8}{|c|}{ Energy use index (EUI, $\mathrm{kWh} / \mathrm{m}^{2} /$ year $):$} \\
\hline TOTAL & $561(100 \%)$ & $348(100 \%)$ & $438(100 \%)$ & $650(100 \%)$ & $552(100 \%)$ & $401(100 \%)$ & $255(100 \%)$ \\
\hline Electricity & $75(13 \%)$ & $63(18 \%)$ & $246(56 \%)$ & $117(18 \%)$ & $192(35 \%)$ & $112(28 \%)$ & $35(13 \%)$ \\
\hline Natural gas & $486(87 \%)$ & $285(82 \%)$ & $192(44 \%)$ & $533(82 \%)$ & $360(65 \%)$ & $289(72 \%)$ & $220(87 \%)$ \\
\hline AVERAGED & $x$ & & 49 & & & & 255 \\
\hline
\end{tabular}

Following the guidelines of screening LCA (Puig et al. 2017), a system boundary was set up for analysis. This included all instances of energy use in hotel operations for such purposes as: guest stay (including laundry), catering, leisure, business. Similar to other studies (Filimonau et al. 2011a), instances of indirect/non-operational energy use (energy embodied in food procurement, hotel's building, furniture and equipment) were excluded from analysis due to data availability.

\section{Results and discussion}

\subsection{Operational energy use}


Figure 2 shows that operational energy consumption in the case study hotels varies significantly across the sample, with Hotels A and F standing out as heavy energy users. For Hotel F, excessive energy use was due to the size of the hotel's property which is the largest in the studied sample (489 guest rooms and GFA of $51800 \mathrm{~m}^{2}$ ), Table 3 . Interviews with the Hotel A's administration revealed that this hotel's excessive energy use was largely attributed to the property's location in the north-east of Iran which is characterised by colder climate (Roshan et al. 2017). This is reflected in excessive use of natural gas (87\% of the total energy consumption) by Hotel A for heating, especially in winter. The physical parameters of the Hotel A also played a role in its excessive energy consumption. In addition to being the second largest hotel within the studied sample in terms of GFA (Table 3), its building is designed in the Y-shape and has a number of outbuildings with multiple exits. This brings about higher energy inefficiency in comparison with a more 'traditional' design of hotel buildings (Sozer 2010). For instance, all other hotels under study are represented by a single building.

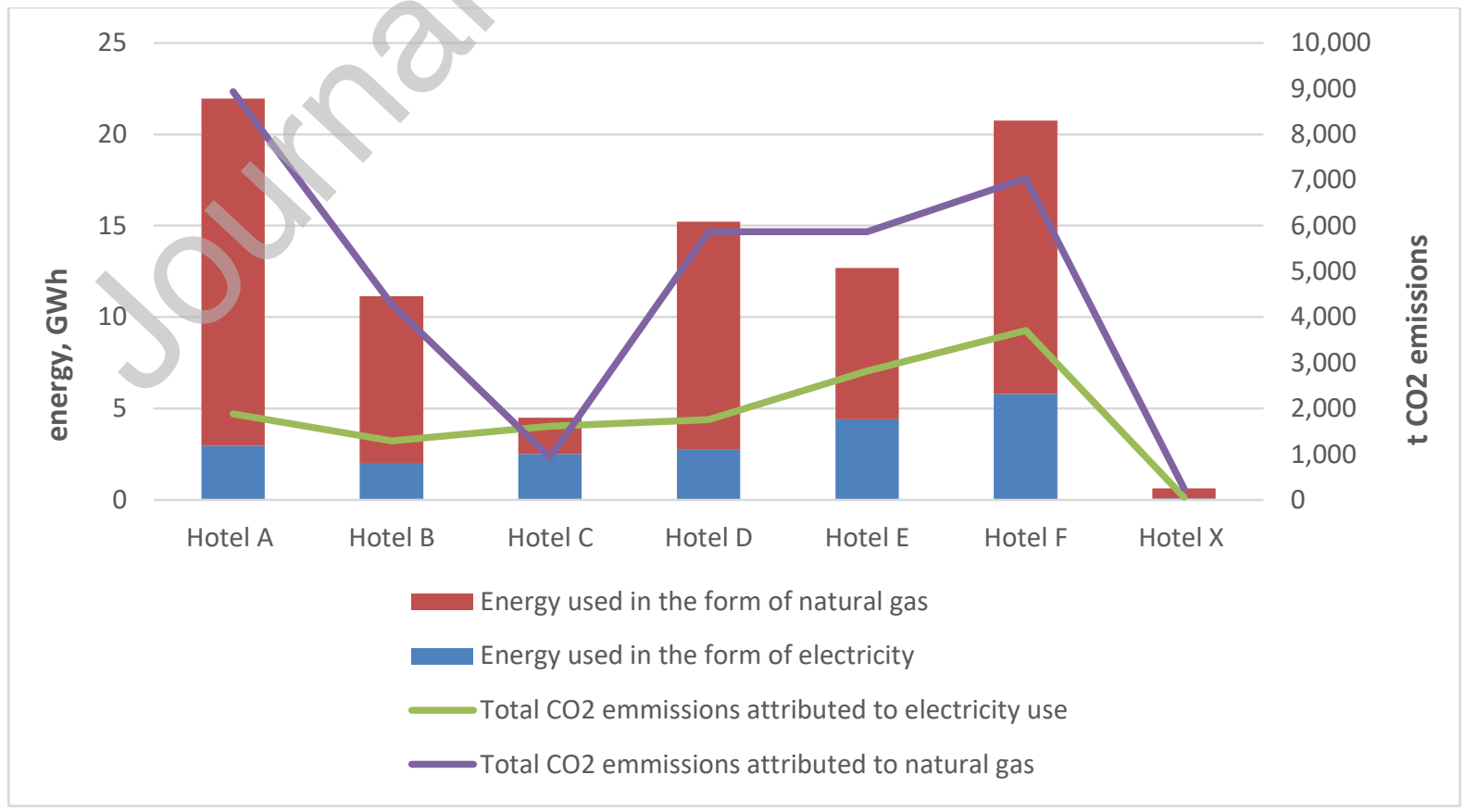

Figure 2. Energy use and carbon emissions of the studied hotels 
Interestingly, despite its larger size (Table 3), Hotel F slightly outperforms Hotel A in terms of energy usage (Figure 2). In addition to the factors of hotel's location and building design discussed above, this is also a result of implementing some energy conservation measures. According to its administration, Hotel $\mathrm{F}$ is one of the first hotels in Iran to begin investing in such technologies as the Building Management Systems (BMS) and Computerised Maintenance Management System (CMMS). These technologies enable Hotel F to more effectively manage energy use compared to Hotel A which has no such technology in place. Hotel $\mathrm{F}$ is located in Tehran which is a mainstay of tourist demand in Iran. The factor of location played an important role in the decision of this hotel's administration to avail of energy saving technologies. Better availability of finance and relevant technologies (Dascalaki and Balaras 2004) alongside growing expectations of international hotel guests of the environmental sustainability measures adopted by hotels (Kasim 2009) represent significant drivers of the industry's investment in energy conservation, which holds true for Iran (Mardani et al. 2016).

Smaller size (Table 3) explained the relatively small energy consumption pattern of Hotel C. If the size of this hotel tripled, thus reaching the figure of other studied luxury hotels within the sample, then its energy use would be comparable to that of Hotel B (Figure 2). Interestingly, however, due to higher occupancy, energy consumption of Hotel $\mathrm{C}$ per guest night is higher than that of Hotel B (Table 4). These findings confirm that size of a hotel's property (Deng and Burnett 2000) and its occupancy rate (Xuchao et al. 2010) represent the major determinants of energy consumption patterns in the hotel sector. Another distinctive feature of Hotel $\mathrm{C}$ is in its over-reliance on electricity (Figure 2). This is attributed to the factor of hotel's location in the south-west of Iran characterised by dry and warm climate (Roshan et al. 2017). In line with this, Hotel C consumes disproportionate energy for airconditioning/cooling/ventilating, especially in spring and summer seasons. 
When energy performance of luxury hotels was compared against that of a low-cost Hotel X, substantial differences were detected. The overall energy use of Hotel X was significantly lower (Figure 2) as it consumed 11 times less energy than Hotel A and almost 5 times less energy than Hotel C. Likewise, calculations per guest night stay indicated that Hotel X consumed 7 times and 2.5 times less energy than Hotel A and C, respectively (Table 4). The main reason behind this is linked to the difference in the availability of guest amenities and services in the studied hotels. For example, whereas the cooling systems in Hotels A-F are central, Hotel X utilizes smaller-scale evaporative coolers. These are installed directly in guest rooms but, unlike central systems where hotel guests can easily adjust the settings of heat/cold via in-room thermostats, these offer limited/no scope for guests' manipulation and/or intervention (Yu and Chan 2006). This technology is more suitable for low-cost hotels not only because it is cheaper to install, but also due to lower expectations of clientele of such hotels of the levels of in-room comfort. Further, although Hotel X provides catering and in-house laundry services to its guests, according to this hotel's administration, these are of smaller-scale and of more limited range compared to Hotels A-F. These findings provide further evidence to the literature which has long established hotel's class/comfort category as a determinant of its energy use patterns (Becken et al. 2001; Lai 2015; Trung and Kumar 2005).

Table 5 compares averaged energy performance of the studied hotels with the figures reported in past research. It shows that luxury hotels in Iran are generally significantly more energy-intense regardless of the unit of analysis. With an averaged value of about $415 \mathrm{kWh}$ per guest night (Table 4), luxury hotels in Iran have no comparable hotels across the world. The closest value of $90 \mathrm{kWh} /$ guest night recorded for some European hotels (Bohdanowicz and Martinac 2007) is more than 4 times lower than the one identified for Iran. In addition, the former number is over a decade old while the Iranian figure is modern. Such significant 
discrepancy is partially attributed to exceptionally low guest occupancy rates in Iranian hotels, i.e. $15-37 \%$ (Table 3), compared against the rate of $84 \%$ typical for London (PwC 2019), for example. This, in turn, is due to the punitive economic sanctions preventing the more rapid development of international tourism in Iran. Another reason might be in the lack of hotel administration's interest in saving energy due to its affordability in Iran.

Further, Table 5 demonstrates that, with an averaged value of about $492 \mathrm{kWh}$ per unit of GFA, the pattern of energy consumption is only similar to the one typical of hotels in Singapore (Xuchao et al. 2010; Priyadarsini et al. 2009) and in Greece (Pieri et al. 2015) - all within the range of 400-500 kWh per unit of GFA. Concurrently, energy use in Iranian luxury hotels is 2.7 times higher than those of their counterparts in China (Sheng et al. 2018) where the lowest pattern of energy consumption has been recorded to date (Table 5). This performance gap can be due to the fact that, unlike in the case of most hotels overseas (Xuchao et al. 2010; Huang et al. 2015; Yao et al. 2015), energy consumption of luxury hotels in Iran is more reliant on natural gas, the combustion of which generates higher energy value than that in Chinese hotels (Sheng et al. 2018), for example. Besides, as stressed by the hotel's administration interviewed, in the result of inadequate manufacturing standards followed by domestic producers in Iran alongside the procurement limitations imposed by punitive international sanctions, energy efficiency of the electric and electronic equipment operated by the case study hotels, especially in the functional areas of kitchen, laundry and powerhouse, is significantly lower compared to that utilized in other geographical markets. The inability to procure modern electric and electronic equipment suggests that energy efficiency of Iranian hotels cannot be improved via retrofitting which holds significant potential to reduce energy intensity of the hotels sector (Xu et al. 2011).

Table 5. Operational energy use and carbon footprint of hotels worldwide. Italics indicate those figures that are similar to the ones identified in this study. 


\begin{tabular}{|c|c|c|c|c|c|c|c|c|}
\hline Source & Location & 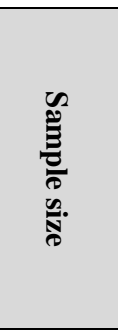 & $\begin{array}{c}\text { Hotel category } \\
\text { LU: luxury, } 5 \text { star/ top class/ } \\
\text { international/ business hotels } \\
\text { UP: up-market/ } 4 \text { star / standard } \\
\text { tourist/ resort hotels } \\
\text { MID: mid-market/ } 3 \text { star/ } \\
\text { general hotels } \\
\text { LC: low comfort/ } 2 \text { star hotels } \\
\text { ONE: } 1 \text { star hotels } \\
\text { UC: unclassified }\end{array}$ & $\begin{array}{c}\text { Average } \\
\text { EUI } \\
\left(\mathbf{k W h} / \mathbf{m}^{2} /\right. \\
\text { year) }\end{array}$ & $\begin{array}{c}\text { Average } \\
\text { kWh// } \\
\text { guest } \\
\text { night/ } \\
\text { year }\end{array}$ & $\begin{array}{l}\text { Average } \\
\mathrm{kg} \mathrm{CO}_{2} \mathrm{e} / \\
\mathrm{m}^{2} / \text { year }\end{array}$ & $\begin{array}{c}\text { Average } \\
\text { kg } \mathrm{CO}_{2} \mathrm{e} / \\
\text { guest } \\
\text { night/ } \\
\text { year }\end{array}$ & $\begin{array}{c}\text { Refere } \\
\text { nce } \\
\text { year of } \\
\text { data }\end{array}$ \\
\hline This study & Iran & 6 & $L U$ & 492 & 415 & 254 & 212 & $2016-17$ \\
\hline \multirow{5}{*}{ Rico et al. (2019) } & \multirow{5}{*}{ Spain } & 6 & LU & - & 62 & - & 22 & \multirow{5}{*}{2016} \\
\hline & & 31 & UP & - & 39 & - & 13 & \\
\hline & & 13 & MID & - & 21 & - & 7 & \\
\hline & & 7 & $\mathrm{LC}$ & - & 12 & - & 4 & \\
\hline & & 7 & ONE & - & 11 & - & 4 & \\
\hline \multirow{3}{*}{ Pérez et al. (2019) } & \multirow{3}{*}{ Spain } & 2 & $\mathrm{LU}$ & - & 70 & - & 38 & \multirow{3}{*}{$\begin{array}{l}2007- \\
2015\end{array}$} \\
\hline & & 7 & UP & - & 21 & - & 12 & \\
\hline & & 3 & MID & - & 12 & - & 6 & \\
\hline Sheng et al. (2018) & China & 310 & $\mathrm{LU}$ & $80-280$ & - & - & - & 2018 \\
\hline Teng et al. (2017) & China & 3 & MID & 92 & - & - & - & 2017 \\
\hline \multirow{3}{*}{ Bianco et al. (2017) } & \multirow{3}{*}{ Italy } & 393 & $\mathrm{LU}$ & $-\frac{2}{2}$ & \multirow[t]{3}{*}{-} & \multirow[t]{3}{*}{-} & \multirow[t]{3}{*}{-} & \multirow{3}{*}{2014} \\
\hline & & 5354 & UP & 230 & & & & \\
\hline & & 15243 & MID & & & & & \\
\hline \multirow{4}{*}{ Puig et al. (2017) } & \multirow{4}{*}{ Spain } & 3 & LU & 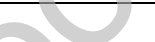 & 56 & \multirow{4}{*}{ - } & 22 & \multirow{4}{*}{$\begin{array}{l}2010- \\
2013\end{array}$} \\
\hline & & 6 & UP & & 31 & & 12 & \\
\hline & & 3 & MID & & 13 & & 3 & \\
\hline & & 2 & LC & & 64 & & 23 & \\
\hline \multirow{4}{*}{$\begin{array}{l}\text { Oluseyi et al. } \\
\text { (2016) }\end{array}$} & \multirow{4}{*}{ Nigeria } & 7 & LU & 307 & \multirow[t]{4}{*}{-} & \multirow[t]{4}{*}{-} & - & \\
\hline & & 7 & UP & 258 & & & & 2014 \\
\hline & & 7 & MID & 318 & & & & 2014 \\
\hline & & 7 & $\mathrm{LC}$ & 142 & & & & \\
\hline & & 9 & $\mathrm{LU}$ & & - & - & $10-50$ & \\
\hline & & 12 & UP & & & & & 2010- \\
\hline Pieri et al. (2015) & Greece & 8 & MID & 420 & & & & 2011 \\
\hline & & 1 & $\mathrm{LC}$ & & & & & \\
\hline & & 15 & $\mathrm{LU}$ & 215 & - & - & - & \\
\hline Yao et al. (2015) & China & 15 & UP & 235 & & & & 2015 \\
\hline & & 15 & MID & 215.7 & & & & \\
\hline & & 39 & LU & 281 & - & 132 & 29 & \\
\hline Huang et al. (2015) & lawwan & 19 & UP & 249 & & & & 2012 \\
\hline Hu et al. (2015) & Taiwan & 1 & LU & - & - & 176 & 157 & $\begin{array}{l}2011- \\
2012\end{array}$ \\
\hline & & 12 & $\mathrm{LU}$ & - & - & - & 29 & \\
\hline Tsai etal (2014) & Taiwan & 7 & UP & & & & 19 & 2011- \\
\hline Tsai et al. (2014) & Taiwan & 22 & MID & & & & 13 & 2012 \\
\hline & & 24 & LC & & & & 6 & \\
\hline Let & Ching & 20 & LU & 132 & 22 & - & - & 2010 \\
\hline Lu et al. (2013) & China & 7 & UP & & 32 & & & 2010 \\
\hline Lai et al. (2012) & $\begin{array}{l}\text { Hong } \\
\text { Kong }\end{array}$ & 1 & UP & - & - & 173 & - & 2012 \\
\hline & & 45 & $\mathrm{LU}$ & 280 & 62 & & - & \\
\hline Wang (2012) & Taimon & 19 & UP & 238 & 55 & & & 2010 \\
\hline Wang (2012) & Taiwan & 116 & MID & 186 & 55 & - & & 2010 \\
\hline & & 20 & $\mathrm{LC}$ & 144 & 24 & & & \\
\hline $\begin{array}{l}\text { Filimonau et al. } \\
\text { (2011a) }\end{array}$ & The UK & 2 & MID & 213 & 13 & 95 & 6 & 2008 \\
\hline & & 11 & LU & & - & & - & \\
\hline (2010) & Singapore & 13 & UP & 427 & & 222 & & 2004 \\
\hline & & 5 & MID & & & & & \\
\hline $\begin{array}{l}\text { Rosselló-Batle et al. } \\
(2010)\end{array}$ & Spain & 2 & UP & 140 & - & 96 & - & 2007 \\
\hline
\end{tabular}




\begin{tabular}{|c|c|c|c|c|c|c|c|c|}
\hline \multirow{3}{*}{$\begin{array}{l}\text { Priyadarsini et al. } \\
\text { (2009) }\end{array}$} & \multirow{3}{*}{ Singapore } & 11 & LU & 458 & \multirow[t]{3}{*}{ - } & \multirow[t]{3}{*}{ - } & \multirow[t]{3}{*}{ - } & \multirow{3}{*}{$\begin{array}{l}2005- \\
2006\end{array}$} \\
\hline & & 13 & UP & 445 & & & & \\
\hline & & 5 & MID & 283 & & & & \\
\hline \multirow{2}{*}{$\begin{array}{l}\text { Bohdanowicz and } \\
\text { Martinac (2007) }\end{array}$} & \multirow{2}{*}{ Europe } & 73 & UP & 364 & 90 & \multirow[t]{2}{*}{ - } & \multirow[t]{2}{*}{ - } & \multirow{2}{*}{2004} \\
\hline & & 111 & MID & 285 & 48 & & & \\
\hline \multirow{3}{*}{$\begin{array}{l}\text { Trung and Kumar } \\
\text { (2005) }\end{array}$} & \multirow{3}{*}{ Vietnam } & 9 & UP & 141 & \multirow[t]{3}{*}{-} & \multirow[t]{3}{*}{-} & \multirow[t]{3}{*}{-} & \multirow{3}{*}{2000} \\
\hline & & 25 & MID & 143 & & & & \\
\hline & & 12 & LC & 101 & & & & \\
\hline $\begin{array}{l}\text { Önüt and Soner } \\
\text { (2005) }\end{array}$ & Greece & 32 & LU & 389 & - & - & - & 2005 \\
\hline \multirow{4}{*}{$\begin{array}{l}\text { Dascalaki and } \\
\text { Balaras (2004) }\end{array}$} & Italy & 1 & MID & 215 & \multirow[t]{4}{*}{-} & \multirow[t]{4}{*}{ - } & \multirow[t]{4}{*}{-} & \multirow{4}{*}{2004} \\
\hline & Greece & 1 & MID & 174 & & & & \\
\hline & France & 1 & MID & 280 & & & & \\
\hline & Spain & 1 & MID & 287 & & & & \\
\hline Becken et al. (2001) & $\begin{array}{c}\text { New } \\
\text { Zealand }\end{array}$ & 30 & $\mathrm{UC}$ & 159 & 43 & - & - & 1999 \\
\hline $\begin{array}{l}\text { Deng and Burnett } \\
(2000)\end{array}$ & $\begin{array}{l}\text { Hong } \\
\text { Kong }\end{array}$ & 16 & $\mathrm{UC}$ & 564 & - & - & - & 1995 \\
\hline $\begin{array}{l}\text { Santamouris et al. } \\
\text { (1996) }\end{array}$ & Greece & 158 & $\mathrm{UC}$ & 273 & - & - & - & 1996 \\
\hline
\end{tabular}

Another substantial gap in energy use can be observed when the discrepancy between the energy performance of Iranian luxury hotels is compared against that of their counterparts in Spain (Puig et al. 2017; Rico et al. 2019 ) and Taiwan (Wang 2012), Table 5. It is argued that this is partially because of the lack of government- and/or industry-driven interventions to monitor and, subsequently, regulate energy usage within the hotel sector of Iran. It is deemed that this is also a result of insufficient awareness among Iranian hoteliers of energy reduction measures and, more importantly, the benefits these measures can provide their businesses with. Indeed, unlike in other countries (Filimonau 2016), the low costs of fossil fuels in Iran may prevent hotel administration from adopting the vision of cost-saving as a prime motivator of investing in energy efficiency. Low environmental awareness of domestic tourists does not prompt hoteliers to reduce energy consumption, suggesting energy conservation can only be driven by the good will of the hotel's administration. Accordingly, the energy conservation measures undertaken by luxury hotels in Iran are not substantially different from those adopted in low-cost hotels, and remain inadequate when compared to international standards (Michailidou et al. 2015). 


\subsection{Operational $\mathrm{CO}_{2}$ emissions}

Figure 2 shows that the $\mathrm{CO}_{2}$ emissions of the studied luxury hotels in Iran are attributed to natural gas consumption with an exception of Hotel $\mathrm{C}$ whose over-reliance on electricity due to its geographical location was explained earlier. The highest share of natural gas in the carbon footprint was recorded for Hotel A (83\%) which is because of the particular building design, size of the property, geographical location, higher number of guest rooms and higher guest occupancy rates. Table 6 compares the carbon performance of the studied hotels. It indicates correlation between higher levels of guest functions and services with the generation of higher amounts of $\mathrm{CO}_{2}$ emissions when calculated both per guest night and per unit of GFA. This is in line with the findings of Tsai et al. (2014) for Taiwanese hotels but contradicts the evidence found in Spanish hotels (Puig et al. 2017). The potential reason for this gap can be in significant variations in the scope and scale of guest services provided by the hotels under study (such as the size of sports and business facilities, in-house restaurants and laundry) alongside differences in the frequency of their use. For example, in-house restaurants in Spain and Taiwan are traditionally popular with hotel guests while, in Iran, due to the cost factor, the use of on-site catering services may be limited. Likewise, conference facilities of luxury hotels are more likely to be used in Spain and/or Taiwan compared to Iran which may, again, be attributed to the affordability factor.

Table 6. $\mathrm{CO}_{2}$ emissions of the surveyed hotels.

\begin{tabular}{|c|c|c|c|c|c|c|c|}
\hline Analysis category & Hotel A & Hotel B & Hotel C & Hotel D & Hotel E & Hotel F & Hotel X \\
\hline \multicolumn{8}{|c|}{ Annual CO2 emissions per guest night (kg/guest night/year) } \\
\hline TOTAL & $427(100 \%)$ & $225(100 \%)$ & $107(100 \%)$ & - & $\begin{array}{c}182 \\
(100 \%)\end{array}$ & $118(100 \%)$ & $38(100 \%)$ \\
\hline Electricity & $74(17 \%)$ & $52(23 \%)$ & $68(64 \%)$ & - & $77(42 \%)$ & $41(35 \%)$ & $7(18 \%)$ \\
\hline Natural gas & $353(83 \%)$ & $173(77 \%)$ & $39(36 \%)$ & - & $105(58 \%)$ & $77(65 \%)$ & $31(82 \%)$ \\
\hline AVERAGED & \multicolumn{6}{|c|}{212} & 38 \\
\hline \multicolumn{8}{|c|}{ Annual CO2 emissions per unit of GFA ( $\mathrm{kg} / \mathrm{m}^{2} /$ year) } \\
\hline TOTAL & $276(100 \%)$ & $174(100 \%)$ & $247(100 \%)$ & $326(100 \%)$ & $292(100 \%)$ & $208(100 \%)$ & $\begin{array}{c}125 \\
(100 \%)\end{array}$ \\
\hline Electricity & $48(17 \%)$ & $40(23 \%)$ & $157(64 \%)$ & $75(23 \%)$ & $123(42 \%)$ & $72(35 \%)$ & $22(18 \%)$ \\
\hline Natural gas & $228(83 \%)$ & $134(77 \%)$ & $90(36 \%)$ & $251(77 \%)$ & $169(58 \%)$ & $136(65 \%)$ & $103(82 \%)$ \\
\hline AVERAGED & \multicolumn{6}{|c|}{254} & 125 \\
\hline
\end{tabular}


Compared to hotels in other markets, the carbon performance of the studied hotels in Iran is poor (Table 5). Whilst the carbon intensity per unit of GFA finds some comparable figures in the context of Singapore (Xuchao et al. 2010), the value of $\mathrm{CO}_{2}$ emissions the studied hotels generate per guest night is disproportionally high and cannot find any analogue in past research. The closest figure of $157 \mathrm{~kg} \mathrm{CO}_{2} /$ guest night/year was recorded for luxury hotels in Taiwan (Hu et al. 2015) but it is almost 35\% lower than the average value identified in this study. The range of figures reported in past research rests within the remit of $22-38 \mathrm{~kg}$ $\mathrm{CO}_{2}$ /guest night/year (Table 5) which is nearly 7 times less than the average value of the Iranian luxury hotels. Interestingly, the carbon footprint of the low-cost hotel in Iran (Hotel $\mathrm{X}, 38 \mathrm{~kg} \mathrm{CO} /$ guest night/year) is higher than the range of figures reported for luxury hotels, let alone low-cost hotels, in other geographical markets, Table 5.

The main reason for this gap is the difference in hotels' popularity and the related low guest occupancy rates. For example, occupancy of 60-90\% was reported for Taiwanese hotels (Tsai et al. 2014) and up to $100 \%$ for hotels in Spain (Puig et al. 2017). This is disproportionally high in comparison with the Iranian context where the figures of $15-37 \%$ were recorded. Lower hotel occupancy brings about higher carbon footprint (Becken et al. 2001; Filimonau et al. 2011a; Trung and Kumar 2005) which is well evidenced in this study.

A number of further reasons can explain the disproportionate discrepancy in carbon performance of luxury hotels in Iran and overseas. First and foremost, compared to the average values of carbon intensities of different fuels available for the UK (DEFRA 2019) and Taiwan (Tsai et al. 2014), the $\mathrm{CO}_{2}$ emission coefficients for energy generation in Iran are significantly higher. For example, while $1 \mathrm{kWh}$ of electricity generation produces an average of $0.64 \mathrm{~kg}$ of $\mathrm{CO}_{2}$ in Iran (Iranian Ministry of Energy 2018-2019), the value of $0.25 \mathrm{~kg}$ of $\mathrm{CO}_{2}$ is reported by DEFRA (2019). Likewise, the carbon intensity of natural gas in Iran is $4.89 \mathrm{~kg} / \mathrm{m}^{3}$ while DEFRA (2019) provides a figure of $2.02 \mathrm{~kg} / \mathrm{m}^{3}$. If the carbon coefficients 
used by DEFRA were employed in this study, the carbon footprint of the studied luxury hotels in Iran would decrease to an average of $102 \mathrm{~kg} / \mathrm{m}^{2} /$ year and $75 \mathrm{~kg} /$ guest night/year and, thus, would create an impression of a better carbon performance compared to some Taiwanese hotels (Hu et al. 2015), for example. Having said this, even with this methodological adjustment, the carbon footprint of luxury hotels in Iran, when calculated per guest night, would still be excessive in comparison with other geographies, Table 5. This clearly shows that the higher carbon intensity of fossil fuels in Iran contributes disproportionately to the carbon footprint of hotel operations.

Second, unlike some of the Spanish 5-star hotels investigated by Puig et al. (2017), the Iranian hotels all operated at a full cycle and all-year-round and made in-house laundry available to their guests. The operational cycle of hotels and the presence of on-site guest services and amenities determine the magnitude of their carbon footprint (Castellani and Sala 2012; Filimonau et al. 2011b; Rosselló-Batle et al. 2010), which finds confirmation in this study.

Third, as mentioned earlier, the studied properties in Iran were less technologically advanced and less frequently retrofitted compared to their European and Asian counterparts which had an effect on their energy efficiency. Fourth, in Iran, there is currently no relevant legislation and/or government's guidelines on energy conservation and carbon audit which is in contrast to other countries, such as the UK, Australia and Taiwan (Lai et al. 2012). Fifth, the absence of international hotel chains in Iran suggests that the industry has developed no corporate policies and/or operational standards in energy and carbon reduction that other hotels could become familiar with and subsequently follow. This is in addition to the lack of nongovernmental organisations and environmental activists in Iran that could impose some pressure on the industry in order to lobby the set-up of environmental conservation targets. Lastly, poor environmental awareness of domestic hotel guests in Iran suggests the industry 
does not have to listen to the environmental concerns of their customers while consumer feedback represents an important motivator for hotels to invest in energy and carbon reduction in other tourism markets (Legrand et al. 2017). Finally, Figure 3 summarizes measures that can be adopted in Iran to achieve better energy and carbon efficiency in (luxury) hotels.

Figure 3. Drivers of poor energy and carbon performance of Iranian luxury hotels and potential strategies towards how these can be addressed.

\begin{tabular}{|c|c|c|c|c|}
\hline \multirow{2}{*}{$\frac{\text { NATURAL }}{\text { Climate and geographical location }}$} & EXTERNAL, NON-NATURAL & \multicolumn{3}{|c|}{ INTERNAL, NON-NATURAL } \\
\hline & Punitive economic sanctions & Institutional & Organisationa & Societal \\
\hline \multirow{3}{*}{$\begin{array}{l}\text { Thermal } \\
\text { comfort }\end{array}$} & \multirow{3}{*}{\begin{tabular}{c||c} 
Unfavourable \\
country's image
\end{tabular}$\| \begin{array}{c}\text { Interrupted flow of } \\
\text { knowledge and capital }\end{array}$} & \multicolumn{3}{|c|}{ Poor, decentralised environmental and tourism governanc } \\
\hline & & \multicolumn{3}{|c|}{ Over-reliance on low cost fossil fuels } \\
\hline & & \multicolumn{3}{|c|}{ Environmental conservation is not a state priority } \\
\hline $\begin{array}{l}\text {-Inadequate building design } \\
\text {-Inappropriate use of building materials } \\
\text {-Unsuitable construction techniques } \\
\text {-Unskilled construction workers }\end{array}$ & $\begin{array}{l}\text {-Limited international tourism } \\
\text {-Lack of internationally branded hotel chains } \\
\text {-Lack of investment } \\
\text {-Lack of novel technologies } \\
\text {-Lack of technological 'know how' }\end{array}$ & \multicolumn{3}{|c|}{$\begin{array}{l}\text {-No environmental conservation targets } \\
\text {-No diversified energy sources } \\
\text {-Lack of corporate environmental awareness } \\
\text {-Lack of environmental awareness among hotel guests } \\
\text { with subsequent irresponsible behaviour }\end{array}$} \\
\hline $\begin{array}{l}\text {-Errors in hotel building construction } \\
\text {-Mistakes in building planning } \\
\text {-Questionable hotel building design }\end{array}$ & $\begin{array}{l}\text {-Lack of pro-environmental corporate policies } \\
\text {-Lack of environmental technologies } \\
\text {-No pressure for hotels to go 'green' } \\
\text {-Limited scope for retrofitting }\end{array}$ & \multicolumn{3}{|c|}{$\begin{array}{l}\text {-Lack of marked-based tools for energy conservation } \\
\text {-Environmental management is not a corporate priority } \\
\text {-No guest pressure on hotels to save the environment } \\
\text {-No voluntary, pro-environmental industry agreements }\end{array}$} \\
\hline $\begin{array}{l}\text {-Design for the environment } \\
\text {-Exchange of good practices } \\
\text {-Expert consultancy } \\
\text {-Foreign expertise and experience }\end{array}$ & $\begin{array}{l}\text {-Pro-active destination marketing } \\
\text {-Incentives for international hotel chains } \\
\text {-Liaised exceptions to sanctions for the transfer of } \\
\text { environmental technologies and 'know how' }\end{array}$ & \multicolumn{3}{|c|}{$\begin{array}{l}\text {-Clear energy conservation and carbon reduction targets } \\
\text {-Financial (dis)incentives for (non-)compliance } \\
\text {-Databases of benchmarking data on energy use in hotels } \\
\text {-Environmental management training for hoteliers } \\
\text {-Public environmental awareness building campaigns }\end{array}$} \\
\hline $\begin{array}{l}\text {-Building and construction legislators } \\
\text {-Hotel management } \\
\text {-Scholars (architects and engineers) }\end{array}$ & $\begin{array}{l}\text {-Policy-makers } \\
\text {-Destination management practitioners } \\
\text {-Industry associations }\end{array}$ & \multicolumn{3}{|c|}{$\begin{array}{l}\text {-Policy-makers } \\
\text {-Hotel management and industry associations } \\
\text {-Environmental and tourism NGOs } \\
\text {-Scholars (social scientists) } \\
\text {-Media }\end{array}$} \\
\hline
\end{tabular}




\section{Conclusions}

The study made a number of theoretical and empirical contributions. From the viewpoint of theory, it provided further evidence to how the method of LCEA can be applied in the hotel sector to assess the energy and carbon performance of tourist accommodation facilities. With a case study of luxury hotels in Iran, this project has proven the scientific rigour and shown the cost-effectiveness of LCEA as a means of understanding the energy and carbon footprint of tourist accommodation. From the empirical perspective, the study provided a first known benchmark of energy consumption and carbon footprint of luxury hotels in Iran, a large Middle East's economy with continuously developing tourism. The study revealed exceptionally high energy and carbon intensity of luxury hotels in Iran when compared to their counter-parts located in other tourism markets. The study further showed a substantial discrepancy in energy and carbon performance of luxury and budget hotels in Iran and outlined the reasons for its occurrence.

The disproportionate energy and carbon intensity of luxury hotels in Iran calls for urgent mitigation measures. The development of these measures should engage multiple stakeholders as manifold factors were found to influence the inadequate energy and carbon performance of Iranian hotels. As a key stakeholder, Iranian policymakers should, at foremost, attempt at easing/lifting the punitive economic sanctions to provide hoteliers with access to the international 'know how' and modern energy conservation technology. They should further set energy conservation and carbon reduction targets for the hotel sector and design a range of market-based tools encouraging Iranian hotels to meet these targets. For example, no/low interest loans can be made available to hoteliers for the adoption of the Building Management Systems (BMS) and Computerised Maintenance Management System (CMMS). Example of Hotel F reviewed in this study showcases the importance of such solutions in the more effective energy management in hotel properties. Renewable energy 
technology, particularly solar, should also be actively promoted among hoteliers given the abundance of sunshine in Iran. Another stakeholder, the Iran Hotel Association, should establish and regularly update a free-to-access database of benchmarks on energy use and carbon emissions for Iranian hotels. This database can stimulate awareness of hotel administrations of the problem of excessive energy use and enable comparisons across hotel properties, thus prompting hoteliers towards energy conservation. The Iran Hotel Association, in cooperation with the Iranian Department of Environment or the Iranian Ministry of Energy, can further provide hotels with relevant guidelines and standards on how to monitor/audit energy use in hotel buildings. Lastly, it can organise hands-on trainings and invite industry experts, from Iran but also from abroad, to demonstrate the benefits of energy reduction and share good business practices in how it can be achieved. Hoteliers, as another stakeholder, should, as a bare minimum, start monitoring energy use in their properties on a regular basis and develop measures encouraging its conservation. In particular, they should encourage hotel guests to save energy by raising their awareness but, also, by incentivizing energy saving behaviour.

As for the limitations of this study, first, the sample was restricted to the highest comfort level of hotels in Iran. As mentioned earlier, this choice was deliberate and, to a large extent, unavoidable given that the energy data essential for this project were treated with complete confidentiality by many Iranian hoteliers. Therefore, sector-typical luxury hotels, deemed to be leading the hotel sector in its progress towards the goal of environmental sustainability, made up the sample of this study. Second, the lack of primary data inventories relating to the non-operational energy and material use of the surveyed hotels hampered this study's initial intention to conduct a 'traditional' LCA, i.e. accounting for the instances of 'indirect' energy and material flows in hotel properties and considering a range of environmental impacts. Such a full-scale study would be more comprehensive, albeit 
exceptionally laborious and, potentially, expensive should, for example, the missing primary data inventories were procured from a commercial provider.

A number of directions for future research can be outlined. The benchmarks of energy and carbon performance established by this study for Iranian luxury hotels can prompt future research to assess the energy and carbon efficiency of other hotel categories in Iran, especially those from one-/two-/three-star classes that dominate the market. Future studies should also attempt at quantifying the non-operational energy use in different hotel categories. By combining non-operational energy with the benchmarks of operational energy consumption established in this study, future research will provide a more holistic understanding of the energy use and carbon footprint patterns in Iranian hotels. Lastly, given the importance of multi-stakeholder involvement in conserving energy in hotels in Iran, the perspectives of such stakeholders as policy-makers, industry representatives, environmental activists and hotel guests should be sought by scholars on how the environmental sustainability agenda can be more actively promoted among Iranian hoteliers.

\section{Declaration}

The authors hereby declare no conflict of interest 


\section{References}

Abaeian, V., Khong, K., Kyid Yeoh, K., \& McCabe, S. (2019). Motivations of undertaking CSR initiatives by independent hotels: a holistic approach. International Journal of Contemporary Hospitality Management, 31(6), 2468-2487.

Abdulredha, M., Rafid, A. L., Jordan, D., \& Alattabi, A. (2017). Facing up to waste: how can hotel managers in Kerbala, Iraq, help the city deal with its waste problem? Procedia Engineering, 196, 771-778.

Aminian, A. (2012). Environmental performance measurement of tourism accommodations in the pilgrimage urban areas: The case of the Holy City of Mashhad, Iran. Procedia-Social and Behavioral Sciences, 35, 514-522.

Arefmanesh, S. (2018). Iran Domestic Tourism Breaks Record in Norouz Holidays. Financial Tribune, 03 April 2018.

Becken, S. (2013). Operators' Perceptions of Energy Use and Actual Saving Opportunities for Tourism Accommodation. Asia Pacific Journal of Tourism Research, 18(1-2), 72-91.

Becken, S., Frampton, C., \& Simmons, D. (2001). Energy consumption patterns in the accommodation sector-the New Zealand case. Ecological Economics, 39(3), 371-386.

Bianco, V., Righi, D., Scarpa, F., \& Tagliafico, L. A. (2017). Modeling energy consumption and efficiency measures in the Italian hotel sector. Energy and Buildings, 149, 329-338.

Blancas, F. J., Lozano-Oyola, M., González, M., \& Caballero, R. (2016). Sustainable tourism composite indicators: A dynamic evaluation to manage changes in sustainability. Journal of Sustainable Tourism, 24(10), 1403-1424. 
Bohdanowicz, P., and Martinac, I. (2007). Determinants and benchmarking of resource consumption in hotels - Case study of Hilton International and Scandic in Europe. Energy and Buildings, 39(1), 82-95.

Castellani, V., \& Sala, S. (2012). Ecological Footprint and Life Cycle Assessment in the sustainability assessment of tourism activities. Ecological indicators, 16, 135-147.

Central Bank of Iran. (2018, June 23). https://www.cbi.ir/showitem/17933.aspx (in Persian)

Chan, C.S., Lee, S.C., Chan, W., Ho, K.F., Tian, L., Lai, S.C., ... \& Huang, Y. (2011).

Characterisation of volatile organic compounds at hotels in southern China. Indoor and Built Environment, 20(4), 420-429.

Chan, W., Lee, S.C., Li, D., \& Chen, X.K. (2017). Cigarette induced PM2.5 in hotel rooms: An assessment of the effectiveness of management's mitigating measures. International Journal of Hospitality Management, 60, 42-47.

Chan, W.C., Chen, Y., Mak, B., Li, D., Huang, Y., Xie, H., \& Hou, G. (2006). Initial Study of Solar Control Film in a Hotel Guest Room in Winter. Energy Systems Laboratory; Texas A\&M University, http://hdl.handle.net /1969.1/5434 [Accessed 8 April 2020].

Chang, H.S., Huh, C., \& Lee, M.J. (2016). Would an energy conservation nudge in hotels encourage hotel guests to conserve?. Cornell Hospitality Quarterly, 57(2), 172-183.

Chen, H., \& Hsieh, T. (2011). An environmental performance assessment of the hotel industry using an ecological footprint. Journal of Hospitality Management and Tourism, 2(1), $1-11$.

Cvelbar, L.K., Grün, B., \& Dolnicar, S. (2017). Which hotel guest segments reuse towels? Selling sustainable tourism services through target marketing. Journal of Sustainable Tourism, 25(7), 921-934. 
Dascalaki, E., \& Balaras, C.A. (2004). XENIOS—a methodology for assessing refurbishment scenarios and the potential of application of RES and RUE in hotels. Energy and Buildings, 36(11), 1091-1105.

De Camillis, C., Raggi, A., \& Petti, L. (2010). Tourism LCA: state-of-the-art and perspectives. The International Journal of Life Cycle Assessment, 15(2), 148-155.

De Grosbois, D., \& Fennell, D. (2011). Carbon Footprint of the Global Hotel Companies: Comparison of Methodologies and Results. Tourism Recreation Research, 36(3), 231-145.

DEFRA. (2019). Greenhouse gas reporting: conversion factors 2019.

https://www.gov.uk/government/publications/greenhouse-gas-reporting-conversion-factors2019 [Accessed 8 April 2020].

Deng, S. M., \& Burnett, J. (2000). A study of energy performance of hotel buildings in Hong Kong. Energy and Buildings, 31(1), 7-12.

Deng, S. M., \& Burnett, J. (2002). Water use in hotels in Hong Kong. International Journal of Hospitality Management, 21(1), 57-66.

Dočekalová, M. P., \& Kocmanová, A. (2016). Composite indicator for measuring corporate sustainability. Ecological Indicators, 61, 612-623.

Dolnicar, S., Knezevic Cvelbar, L., \& Grün, B. (2017). Do pro-environmental appeals trigger pro-environmental behavior in hotel guests?. Journal of Travel Research, 56(8), 988-997.

Dolnicar, S., Knezevic Cvelbar, L., \& Grün, B. (2019). Changing service settings for the environment. Annals of Tourism Research, 76(C), 301-304.

El Hanandeh, A. (2013). Quantifying the carbon footprint of religious tourism: the case of Hajj. Journal of Cleaner Production, 52, 53-60. 
Elimelech, E., Ayalon, O., \& Ert, E. (2018). What gets measured gets managed: A new method of measuring household food waste. Waste Management, 76, 68-81.

Erdogan, N., \& Baris, E. (2007). Environmental protection programs and conservation practices of hotels in Ankara, Turkey. Tourism Management, 28(2), 604-614.

Fazelpour, F., Soltani, N., \& Rosen, M. A. (2014). Feasibility of satisfying electrical energy needs with hybrid systems for a medium-size hotel on Kish Island, Iran. Energy, 73, 856-865.

Filimonau, V. (2016). Life Cycle Assessment (LCA) and Life Cycle Analysis in Tourism. A Critical Review of Applications and Implications. Springer, Cham.

Filimonau, V., \& Krivcova, M. (2017). Restaurant menu design and more responsible consumer food choice: An exploratory study of managerial perceptions. Journal of Cleaner Production, 143, 516-527.

Filimonau, V., Dickinson, J., Robbins, D., \& Huijbregts, M. (2011a). Reviewing the carbon footprint analysis of hotels: Life Cycle Energy Analysis (LCEA) as a holistic method for carbon impact appraisal of tourist accommodation. Journal of Cleaner Production, 19(1718), 1917-1930.

Filimonau, V., Dickinson, J., Robbins, D., and Reddy, M.V. (2011b). A critical review of methods for tourism climate change appraisal: life cycle assessment as a new approach. Journal of Sustainable Tourism, 19(3), 301-324.

Filimonau, V., Dickinson, J., Robbins, D., \& Reddy, M. V. (2013). The role of 'indirect'greenhouse gas emissions in tourism: Assessing the hidden carbon impacts from a holiday package tour. Transportation Research Part A: Policy and Practice, 54, 78-91.

Frischknecht, R., Althaus, H.J., Bauer, C., Heck, T., Yungbluth, N., ... \& Nemecek, T (2007). The environmental relevance of capital goods in life cycle assessments of products and services. The International Journal of Life Cycle Assessment, 12, 7-17. 
Gabarda-Mallorquí, A., Garcia, X., \& Ribas, A. (2017). Mass tourism and water efficiency in the hotel industry: A case study. International Journal of Hospitality Management, 61, 82-93.

Gardetti, M.A., and Torres, A.L., 2017. Sustainability in hospitality. How innovative hotels are transforming the industry. Oxon, Routledge.

Ge, M., and Friedrich, J., (2020, February 6). 4 Charts Explain Greenhouse Gas Emissions by Countries and Sectors. World Resource Institute.

https://www.wri.org/blog/2020/02/greenhouse-gas-emissions-by-country-sector [Accessed 8 April 2020].

Ghaderi, Z., Mirzapour, M., Henderson, J.C., \& Richardson, S. (2019). Corporate social responsibility and hotel performance: A view from Tehran, Iran. Tourism Management Perspectives, 29, 41-47.

Goldstein, N.J., Cialdini, R.B., \& Griskevicius, V. (2008). A room with a viewpoint: Using social norms to motivate environmental conservation in hotels. Journal of Consumer Research, 35(3), 472-482.

Gössling, S., Araña, J.E., \& Aguiar-Quintana, J.T. (2019). Towel reuse in hotels: Importance of normative appeal designs. Tourism Management, 70, 273-283.

Gössling, S., Hansson, C. B., Hörstmeier, O., \& Saggel, S. (2002). Ecological footprint analysis as a tool to assess tourism sustainability. Ecological economics, 43(2-3), 199-211.

Hu, A.H., Huang, C.Y., Chen, C.F., Kuo, C.H., \& Hsu, C.W. (2015). Assessing carbon footprint in the life cycle of accommodation services: the case of an international tourist hotel. International Journal of Sustainable Development \& World Ecology, 22(4), 313-323.

Huang, K.T., Wang, J.C., \& Wang, Y.C. (2015). Analysis and benchmarking of greenhouse gas emissions of luxury hotels. International Journal of Hospitality Management, 51, 56-66. 
Hunter, C., \& Shaw, J. (2007). The ecological footprint as a key indicator of sustainable tourism. Tourism management, 28(1), 46-57.

ICHHTO. (2018-2019). The performance report-the second year of the sixth plan. https://www.mcth.ir/documents?EntryId=79 (in Persian) [Accessed 8 April 2020].

ICHHTO. (2019-2020). Statistical yearbook of 1397 (2018-2019).

https://www.mcth.ir/documents?EntryId=79 (in Persian) [Accessed 8 April 2020].

Iranian Ministry of Energy. (2018-2019). Energy balance sheet of 1395 (2016-2017).

http://pep.moe.gov.ir (in Persian) [Accessed 8 April 2020].

Joint Research Centre-European Commission. (2008). Handbook on constructing composite indicators: methodology and user guide. OECD.

Kahn, M.E., Kok, N., \& Liu, P. (2016). Is California More Energy Efficient than the Rest of the Nation? Evidence from Commercial Real Estate (No. w21912). National Bureau of Economic Research.

Kallbekken, S., \& Sælen, H. (2013). 'Nudging'hotel guests to reduce food waste as a winwin environmental measure. Economics Letters, 119(3), 325-327.

Kasim, A. (2009). Managerial attitudes towards environmental management among small and medium hotels in Kuala Lumpur. Journal of Sustainable Tourism, 17(6), 709-725.

Kelly, J., \& Williams, P.W. (2007). Modelling Tourism Destination Energy Consumption and Greenhouse Gas Emissions: Whistler, British Columbia, Canada. Journal of Sustainable Tourism, 15(1), 67-90.

Khodadadi, M. (2016a). A new dawn? The Iran nuclear deal and the future of the Iranian tourism industry. Tourism Management Perspectives, 18, 6-9. 
Khodadadi, M. (2016b). Return to glory? Prospects of Iran's hospitality sector post-nuclear deal. Tourism Management Perspectives, 19, 16-18.

Kim, H., \& Oldham, E. (2017). Long-term field investigation and modeling of electricity end use patterns in hotel guest rooms. Energy and Buildings, 155, 414-424.

Klöpffer, W. (2003). Life-Cycle based methods for sustainable product development. The International Journal of Life Cycle Assessment, 8, 157-159.

Koiwanit, J., and Filimonau, V. (2021). Carbon footprint assessment of home-stays in Thailand. Resources, Conservation and Recycling, 164, 105123.

Lai, J.H. (2015). Carbon footprints of hotels: Analysis of three archetypes in Hong Kong. Sustainable Cities and Society, 14, 334-341.

Lai, J.H., Yik, F.W., \& Man, C.S. (2012). Carbon audit; a literature review and an empirical study on a hotel. Facilities, 30, 417-431.

Lai, J.H.K. (2015). Carbon footprints of hotels: Analysis of three archetypes in Hong Kong. Sustainable Cities and Society, 14, 334-341.

Legrand, W., Sloan, P., \& Chen, J.S. (2017). Sustainability in the hospitality industry: principles of sustainable operations. Routledge. Oxon.

Lenzen, M., Sun, Y-Y., Faturay, F., Ting, Y-P., Geschke, A., and Malik, A. (2018). The carbon footprint of global tourism. Nature Climate Change, 8, 522-528.

Lu, S., Wei, S., Zhang, K., Kong, X., \& Wu, W. (2013). Investigation and analysis on the energy consumption of starred hotel buildings in Hainan Province, the tropical region of China. Energy Conversion and Management, 75, 570-580. 
Mak, B.L., Chan, W.W., Li, D., Liu, L., \& Wong, K.F. (2013). Power consumption modeling and energy saving practices of hotel chillers. International Journal of Hospitality Management, 33, 1-5.

Mardani, A., Zavadskas, E. K., Streimikiene, D., Jusoh, A., Nor, K. M., \& Khoshnoudi, M. (2016). Using fuzzy multiple criteria decision making approaches for evaluating energy saving technologies and solutions in five star hotels: A new hierarchical framework. Energy, $117,131-148$.

Mclennan, C.L.J., Becken, S., \& Stinson, K. (2017). A water-use model for the tourism industry in the Asia-Pacific region: The impact of water-saving measures on water use. Journal of Hospitality \& Tourism Research, 41(6), 746-767.

Mendola, D., \& Volo, S. (2017). Building composite indicators in tourism studies: Measurements and applications in tourism destination competitiveness. Tourism Management, 59, 541-553.

Mensah, I. (2006). Environmental management practices among hotels in the greater Accra region. International Journal of Hospitality Management, 25(3), 414-431.

Mensah, I., \& Blankson, E.J. (2013). Determinants of hotels' environmental performance: Evidence from the hotel industry in Accra, Ghana. Journal of Sustainable Tourism, 21(8), $1212-1231$.

Michailidou, A.V., Vlachokostas, C., \& Moussiopoulos, N. (2015). A methodology to assess the overall environmental pressure attributed to tourism areas: A combined approach for typical all-sized hotels in Chalkidiki, Greece. Ecological Indicators, 50, 108-119.

Michopoulos, A., Ziogou, I., Kerimis, M., \& Zachariadis, T. (2017). A study on hot-water production of hotels in Cyprus: Energy and environmental considerations. Energy and Buildings, 150, 1-12. 
Morakabati, Y. (2011). Deterrents to tourism development in Iran. International Journal of Tourism Research, 13(2), 103-123.

National Climate Change Office (NCCO). (2010). Iran second communication to UNFCCC. https://unfccc.int/resource/docs/natc/iranc2.pdf [Accessed 8 April 2020].

Neugebauer, S., Bolz, M., Mankaa, R., \& Traverso, M. (2020). How sustainable are sustainability conferences?-Comprehensive Life Cycle Assessment of an international conference series in Europe. Journal of Cleaner Production, 242, 118516.

Oluseyi, P.O., Babatunde, O.M., and Babatunde, O.A. (2016). Assessment of energy consumption and carbon footprint from the hotel sector within Lagos, Nigeria. Energy and Buildings, 118, 106-113.

Önüt, S., \& Soner, S. (2006). Energy efficiency assessment for the Antalya Region hotels in Turkey. Energy and Buildings, 38(8), 964-971.

Pablo-Romero, M.D.P., Pozo-Barajas, R., \& Sánchez-Rivas, J. (2019). Tourism and temperature effects on the electricity consumption of the hospitality sector. Journal of Cleaner Production, 240, 118168.

Patterson, T.M., Niccolucci, V., \& Bastianoni, S. (2007). Beyond "more is better": ecological footprint accounting for tourism and consumption in Val di Merse, Italy. Ecological Economics, 62(3-4), 747-756.

Pieri, S.P., \& Santamouris, M. (2015). Identifying energy consumption patterns in the Attica hotel sector using cluster analysis techniques with the aim of reducing hotels' $\mathrm{CO} 2$ footprint. Energy and Buildings, 94, 252-262.

Pirani, S.I., \& Arafat, H.A. (2016). Reduction of food waste generation in the hospitality industry. Journal of Cleaner Production, 132, 129-145. 
Pérez, F. J. D., Chinarro, D., Mouhaffel, A. G., Martín, R. D., \& Otín, M. R. P. (2019).

Comparative study of carbon footprint of energy and water in hotels of Canary Islands regarding mainland Spain. Environment, Development and Sustainability, 21(4), 1763-1780.

Priyadarsini, R., Xuchao, W., \& Eang, L.S. (2009). A study on energy performance of hotel buildings in Singapore. Energy and buildings, 41(12), 1319-1324.

Puig, R., Kilic, E., Navarro, A., Alberti, J., Chacon, L., \& Fullana-i-Palmer, P. (2017). Inventory analysis and carbon footprint of coastland-hotel services: A Spanish case study. Science of the Total Environment, 595, 244-254.

PwC (2019). Room supply surge checks growth pace. PwC, London, https://www.pwc.co.uk/hospitality-leisure/assets/pwc-uk-hotels-update-2019-2020.pdf [Accessed 8 April 2020].

Ren, Z., Chrysostomou, V., \& Price, T. (2012). The measurement of carbon performance of construction activities. Smart and Sustainable Built Environment, 1(2), 153-171.

Rico, A., Martínez-Blanco, J., Montlleó, M., Rodríguez, G., Tavares, N., Arias, A., \& OliverSolà, J. (2019). Carbon footprint of tourism in Barcelona. Tourism Management, 70, 491504.

Roshan, G. R., Ghanghermeh, A. A., \& Attia, S. (2017). Determining new threshold temperatures for cooling and heating degree day index of different climatic zones of Iran. Renewable Energy, 101, 156-167.

Rosselló-Batle, B., Moià, A., Cladera, A., \& Martínez, V. (2010). Energy use, CO2 emissions and waste throughout the life cycle of a sample of hotels in the Balearic Islands. Energy and Buildings, 42(4), 547-558.

Salvati, L., \& Carlucci, M. (2014). A composite index of sustainable development at the local scale: Italy as a case study. Ecological Indicators, 43, 162-171. 
Santamouris, M., Balaras, C.A., Dascalaki, E., Argiriou, A., Gaglia, A. (1996). Energy conservation and retrofitting potential in Hellenic hotels. Energy and Buildings, 24, 65-75.

Schianetz, K., Kavanagh, L., \& Lockington, D. (2007). Concepts and tools for comprehensive sustainability assessments for tourism destinations: A comparative review. Journal of Sustainable Tourism, 15(4), 369-389.

SCI (2020). National visitor survey- the spring of 2019.

https://www.amar.org.ir/Portals/0/News/1398/gardesh1-98.pdf (in Persian) [Accessed 8 April 2020].

Sheng, Y., Miao, Z., Zhang, J., Lin, X., \& Ma, H. (2018). Energy consumption model and energy benchmarks of five-star hotels in China. Energy and Buildings, 165, 286-292.

Shiming, D., \& Burnett, J. (2002). Energy use and management in hotels in Hong Kong. International Journal of Hospitality Management, 21(4), 371-380.

Sieghart, L.C., \& Betre, M. (2018). Climate Change in MENA: Challenges and Opportunities for the World's most water stressed region. World Bank.

Singh, N., Cranage, D.A., \& Nath, A. (2014). Estimation of GHG emission from hotel industry. Anatolia, 25(1), 39-48.

Sourvinou, A., and Filimonau, V. (2018). Planning for an environmental management programme in a luxury hotel and its perceived impact on staff: an exploratory case study. Journal of Sustainable Tourism, 26(4), 649-667.

Sozer, H. (2010). Improving energy efficiency through the design of the building envelope. Building and Environment, 45(12), 2581-2593.

Stang, G. (2016). Climate challenges in the Middle East: rethinking environmental cooperation. Middle East Institute. 
Statistical Centre of Iran (SCI). (2017-2018). Statistic yearbook of 1395 (2016-2017)- trade and hotels.

Teng, C-C., Horng, J-S., Hu, M-L., Chien, L-H., Shen, Y-C. (2012). Developing energy conservation and carbon reduction indicators for the hotel industry in Taiwan. International Journal of Hospitality Management, 31(1), 199-208.

Teng, Z.R., Wu, C.Y., \& Xu, Z.Z. (2017). New energy benchmarking model for budget hotels. International Journal of Hospitality Management, 67, 62-71.

Tortella, B.D., \& Tirado, D. (2011). Hotel water consumption at a seasonal mass tourist destination. The case of the island of Mallorca. Journal of environmental management, 92(10), 2568-2579.

Trung, D.N., \& Kumar, S. (2005). Resource use and waste management in Vietnam hotel industry. Journal of Cleaner Production, 13(2), 109-116.

UNWTO. (2017). International tourism highlights. 2017 edition. UNWTO, Madrid, Spain. UNWTO. (2018). International tourism highlights. 2018 edition. UNWTO, Madrid, Spain. UNWTO. (2019). International tourism highlights. 2019 edition. UNWTO, Madrid, Spain. Wackernagel, M., \& Rees, W. (1996). Our ecological footprint: reducing human impact on the earth. Gabriola Island, BC, Canada: New Society Publishers, pp. 221-215.

Wang, J.C. (2012). A study on the energy performance of hotel buildings in Taiwan. Energy and Buildings, 49, 268-275.

Warnken, J., Bradley, M., \& Guilding, C. (2004). Exploring methods and practicalities of conducting sector-wide energy consumption accounting in the tourist accommodation industry. Ecological Economics, 48(1), 125-141. 
Warren, C., \& Becken, S. (2017). Saving energy and water in tourist accommodation: A systematic literature review (1987-2015). International Journal of Tourism Research, 19(3), 289-303.

Wolf, M.A., Pant, R., Chomkhamsri, K., Sala, S., \& Pennington, D. (2012). The International Life Cycle Data system (ILCD) Handbook. JRC reference reports. European Commission, 2012.

WTO and ITF-World Tourism Organization and International Transport Forum, 2019. Transport-related CO2 Emissions of the Tourism Sector-Modelling Results. UNWTO, Madrid.

WTTC. (2018). Travel and tourism economic impact. 2018 edition. WTTC, London, United Kingdom.

World Wild Fund-WWF (2002). Holiday Footprinting: A Practical Guide for Responsible Tourism. World Wildlife Fund UK, pp. 1-38.

Xu, P., Chan, E.H-W., and Qian, Q.K. (2011). Success factors of energy performance contracting (EPC) for sustainable building energy efficiency retrofit (BEER) of hotel buildings in China. Energy Policy, 39(11), 7389-7398.

Xuchao, W., Priyadarsini, R., \& Siew E.L. (2010). Benchmarking energy use and greenhouse gas emissions in Singapore's hotel industry. Energy Policy, 38, 4520-4527.

Yao, Z., Zhuang, Z., \& Gu, W. (2015). Study on energy use characteristics of hotel buildings in Shanghai. Procedia Engineering, 121, 1977-1982.

Yu, F.W., and Chan, K.T. (2006). Economic benefits of improved condenser features for aircooled chillers serving an air-conditioned hotel. Applied Thermal Engineering, 26(10), 1063 1073. 
Zhang, J.J., Joglekar, N., \& Verma, R. (2010). Developing measures for environmental sustainability in hotels: An exploratory study. Cornell Hospitality Report, 10 (8), 6-20.

Zhao, X., Ma, C., \& Gu, P. (2012). Energy saving methods and results analysis in the hotel. Energy Procedia, 14, 1523-1527. 